\title{
Sedimentary environment and provenance of sandstones from the Qadir member in the Nayband Formation, Tabas block, east-central Iran
}

\author{
Ambiente sedimentario y procedencia de las areniscas del miembro Qadir de la Formación Nayband, \\ bloque de Tabas, centro-este de Irán
}

Ehsan Zamaniyan ${ }^{1}$, Mohammad Khanehbad ${ }^{1, *}$, Reza Moussavi-Harami ${ }^{1}$,Asadollah Mahboubi ${ }^{1}$

\begin{abstract}
Department of Geology, Faculty of Science, Ferdowsi University of Mashhad, Azadi Square, Mashhad, Iran.

* Corresponding author: (M. Khanehbad) mkhanehbad@ferdowsi.um.ac.ir
\end{abstract}

\begin{abstract}
Qadir Member of Nayband Formation, located in East of Central Iran, has developed to a great extent. Investigation of the lithofacies and sedimentary environment, resulted in identification of the deltaic and marine deposits. Based on field evidence and facies features, Qadir Member consists of two lithofacies, including carbonate and siliciclastic facies. The siliciclastic facies were identified as having four sandstone facies including Sr, Sh, Sp, St, three finegrained lithofacies, including FI, Fm, Fl $(\mathrm{Sr}) / \mathrm{Sr}(\mathrm{FI})$ and one coal facies. Also, regarding the field, laboratory studies, and identification of lithofacies, the coastal plain, deltaic (including deltaic plain, proximal delta front, distal delta front, and prodelta) and open marine environments were identified for Qadir Member which is is under the impact of tidal currents. The chemical weathering index $(71 \%)$ indicated semi-arid to semi-humid conditions and plotting the geochemical data showed the provenance of re-cycling and active continental margin and because of Chemical Index of Alteration, the weathering rate was found to be rather medium to high. The geochemical diagrams also showed a probable source of the intermediate igneous and sedimentary rocks. The active continental margin conditions for this deposit could suggest the Neotethys subduction under Iran's plate and volcanic activity at the end of Triassic, which coincided with the early Cimmerian orogeny in Alborz and Central East Iranian Microcontinent.
\end{abstract}

Universidad Nacional Autónoma de México.

This is an open access article under the CC BY-NC-SA license(https://creativecommons.org/licenses/by-nc-sa/4.0/)
Keywords: Nayband Formation, Triassic, Tabas Block, Sedimentary environment, Provenance.

\section{RESUMEN}

El miembro Qadir de la Formación Nayband, ubicada en el este del centro de Irán, se ha desarrollado en gran medida. La investigación de la litofacies y el medio sedimentario resultó en la identificación de los depósitos deltaicos y marinos. Basado en evidencia de campo y características de facies, Qadir Member consta de dos litofacies, incluidas facies de carbonato y siliciclástico. Se identificó que las facies siliciclásticas tenian cuatro facies de arenisca, incluidas Sr, Sh, Sp, St, tres litofacies de grano fino, incluidas FI, Fm, Fl (Sr) / Sr (FI) y una facies de carbón. Además, con respecto al campo, los estudios de laboratorio y la identificación de litofacies, se identificaron la llanura costera, deltaica (incluida la llanura deltaica, frente deltaico proximal, frente delta distal y prodelta) y ambientes marinos abiertos para el Miembro Qadir que se encuentra bajo el impacto. de las corrientes de marea. El indice de meteorización química $(71 \%)$ indicó condiciones semiáridas a semihúmedas y el trazado de los datos geoquímicos mostró la procedencia del reciclaje y el margen continental activo y, debido al indice químico de alteración, la tasa de meteorización resultó ser bastante media. en lo alto. Los diagramas geoquímicos también mostraron una fuente probable de rocas ígneas y sedimentarias intermedias. Las condiciones del margen continental activo para este depósito podrían sugerir la subducción de Neotethys bajo la placa de Irán y la actividad volcánica al final del Triásico, que coincidió con la orogenia cimeria temprana en Alborz y el microcontinente irani centro-este.

Palabras clave: Formación Nayband, Triásico, Bloque Tabas, Ambiente sedimentario, Procedencia. 


\section{Introduction}

Examination of sedimentary facies is one of the most important tools in identifying sedimentary environments and interpreting sedimentation processes in different areas. Investigation of sedimentary facies is a very good basis for sedimentology studies to interpret global sea-level changes (Geel, 2000). One of the most important ways to identify and determine facies and interpret the sedimentary environment is the use of lithology data including field studies, petrography, or geochemical analyses (Flugel, 2010). Accordingly, facies analysis identifies sedimentological features that include grain size, texture, and sedimentary structures, while facies associations characterize the alteration of sedimentation processes in the sedimentary environment (Aboumaria et al., 2009). Since lithofacies are controlled and formed by sedimentation processes in sedimentary environments, the study and identification of lithofacies are a great help in the interpretation of syn-sedimentation processes (Catuneanu, 2003).

Also, the relation of tectonic setting, provenance, and composition of siliciclastic rocks has been investigated by many researchers (Dickinson and Suczek, 1979; Bhatia and Crook, 1986; Quanren et al., 2002; Tijani et al., 2010; Ozkan and Ayaz-Bozdag, 2011; Mishra and Sen, 2012; Zhang et al., 2014; Fleming et al., 2016, Fathy et al., 2018; Sabbagh Bajestani et al., 2018; Iqbal et al., 2019; Zamaniyan et al., 2019), because the interpretation of provenance could be used to identify the pre-sedimentary history and reconstruction as well as interpretation of initial erosion of the source rock up to the final deposition and burial history of rocks (Weltje, 2002; Weltje and Von Eynatten, 2004; Khanehbad et al., 2012a, 2012b). Clastic modal analysis of sandstones is employed to identify the tectonic settings and the relationships of sandstone compositions and their provenance (Dickinson and Suczek, 1979; Dickinson et al., 1983; Dickinson, 1985; Critelli, 1993). The tectonic setting is considered to be one of the major controlling factors for sedimentary compositions (Dickinson, 1985). Accordingly, in addition to petrography and facies analyses, investigation of provenance (tectonic setting, source region, and paleoweathering of the original region) has always been the center of attention. Nowadays, the geochemical studies and the implementation of discriminant diagrams have been used as an effective tool to identify the siliciclastic rocks. This study aims to investigate and interpret the sedimentary environment and provenance of siliciclastic deposits of the Qadir Member of the Nayband Formation in the east of Central Iran (Tabas Block) through the field studies, petrography and modal analysis along with geochemical methods. Our results can be used for reconstruction of the paleogeography of eastern part of Central Iran during Late Triassic.

\section{Geological Setting}

The study area is located in the central part of Central East Iranian Microcontinent (CEIM). Tabas Basin is an intra-continental depression and a part of the CEIM witch has experienced a complex structural history (Aghanabati, 2006). The tectonic movements of Early Cimmerian at the end of the Middle to Late Triassic time played an important role in forming Iran's geology in the Late Triassic and Jurassic. At this time, the shallow coastal-continental basins, in addition to siliciclastic rocks, caused the coal-bearing sequences to be formed between the two tectonic occurrences of Early Cimmerian to Middle Cimmerian orogeny (Wilmsen et al., 2009a). After the occurrence of Early Cimmerian orogeny, because of the sea level rise, Nayband Formation (Late Triassic) with the thickness of $3000 \mathrm{~m}$ was deposited in Central Iran's sedimentary structural zone and the type section has been measured and introduced in south of the Nayband Mountain (the West of Nayband village; Aghanabati, 2006). The Late Triassic (Norian-Rhaetian) Nayband Formation is distributed over a large area in central and eastern part of Iran (Seyed-Emami, 2003). Five members have been recognized at the type section of the formation (Bronifman et al., 1971; Kluyver et al., 1983; Aghanabati, 2006), which are from the 
base to the top: 1- Gelkan Member, 2- Bidestan Member, 3- Howz-e-Sheikh Member, 4- Howze-Khan Member, and 5- Qadir Member. The Nayband Formation contains rich benthic macrofauna, including bivalves, corals, diverse groups of sponges, subordinate elements of brachiopods, echinoderms, and gastropods (Fürsich et al., 2005). Based on the studies, the age of Nayband Formation goes back to Late Triassic (Norian to Rhaetian; Nützel et al., 2010; Cirilli et al., 2005; Fürsich et al., 2005). According to Iran's geological divisions (Aghanabati, 2006), part of the studied region of Tabas Block is located in Central Iran's sedimentary structural zone between the large Nayband fault in the east and Kalmard-Kuhbanan fault in the west. The Qadir Member of the Nayband Formation in Parvadeh Coal Mine section $\left(33^{\circ} 00^{\prime} 21^{\prime \prime} \mathrm{N}\right.$ and $\left.56^{\circ} 48^{\prime} 40^{\prime \prime} \mathrm{E}\right)$ is located about $80 \mathrm{Km}$ south of Tabas and has been measured and studied in the north of Nayband sedimentary structural sub-block (subdivisions of Tabas Block; Figures $1 \mathrm{a}$ and $1 \mathrm{~b}$ ). This formation outcrops in a vast area of Tabas Block and one of the best outcrops of this formation is located in the Parvadeh Coal Mine zone in the south of Tabas. Nayband Formation in the southern flank of the central anticline of Parvadeh Coal Mine has $450 \mathrm{~m}$ of thickness (Figure 1c) and in terms of lithology, it includes sandstone, shale, siltstone, coal bearing and fossiliferous limestone.
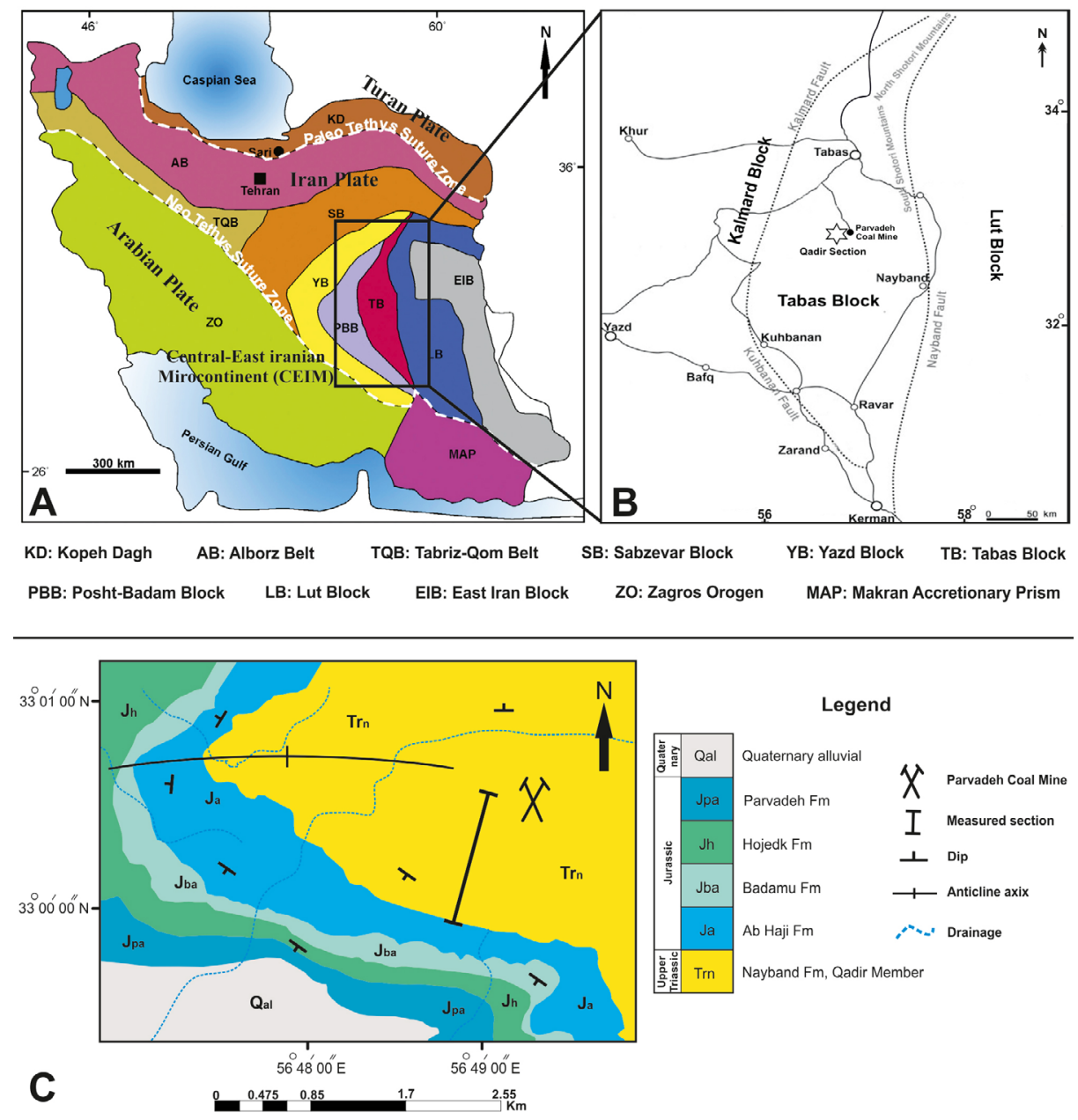

Figure 1 A) The general map of Iran's sedimentary structural zone (adopted and changed from Motiei, 1994), B) The location of the studied section (asterisk) in Tabas Block between Nayband and Kalmard-Kuhbanan faults, C) Sequence position studied on the geological map of Parvadeh Coal Mine area (by draw again of Korit (Moussavi-Harami and Ghaemi, 2006) and Gharb-E-Shekasteh Abshaleh (Saidi et al., 2004) geological maps with a scale of 1:100000). 


\section{Materials and Methods}

The Qadir Member with $450 \mathrm{~m}$ of thickness has been measured and studied in Parvadeh Coal Mine section in the south of Tabas (Figures 2 and 3). After sampling, 86 thin sections were investigated for petrography. To analyze the sedimentary facies of Qadir Member, it has been attempted to sample sedimentary structures, geometrical and lithological features as well as lateral and vertical changes of sedimentary deposits completely. The facies codes by the method of Miall (2000, 2006) were used to identify lithofacies, while Folk's (1980) classification was used to label and identify petrofacies, Dunham (1962) was employed classification for calcareous facies, and Flugel (2010) classification to determine standard microfacies, Dill et al. (1988) and Jones and Manning (1994) for determine and understand the paleo-oxygenation condition. Also, Grabau's (1904) classification was used to label limestones in the field. The names of the sandstones have also been determined using the classifications of Pettijohn et al., 1987, and Folk (1980), as the most common and widely used methods in sandstone classification with particular importance, and the modal analysis data and detrital modes has been performed on 15 samples of medium-grained sandstone with at least 300 points per sample (Tables 1and 2) by the Dickinson method (Ingersoll and Suczek, 1979; Dickinson and Suczek, 1979; Dickinson, 1985). Also, based on the thin section studies, 10 samples of well-sorted sandstones, having the least rate of weathering and the least amount of carbonate (less than 5 percent), were selected for XRF geochemical analysis to determine major and trace elements. The sandstone samples were analyzed by East Amethyst analytical geological lab, using the X-ray fluorescence device (Philips PW 1480 $\mathrm{X}$-ray spectrometer).

\section{Results}

\subsection{LITHOSTRATIGRAPHY}

Qadir Member of the Nayband Formation in this section is mainly consists of shale and sandstone sediments with intercalation of fossiliferous limestone and coal layers (Figures 2 and 3).

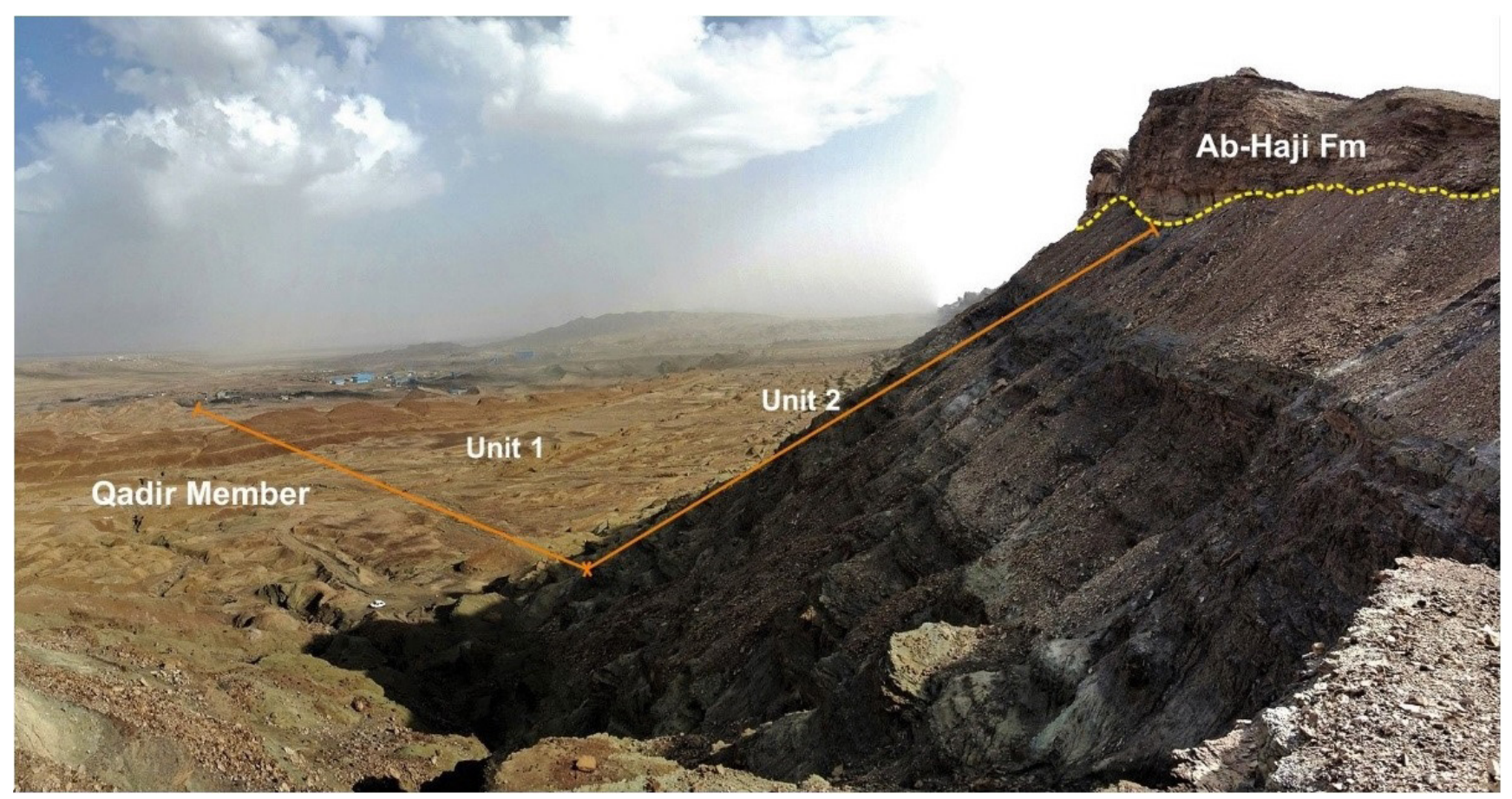

Figure 2 General landscape of Qadir Member section in the Parvadeh Coal Mine area, south of Tabas. 


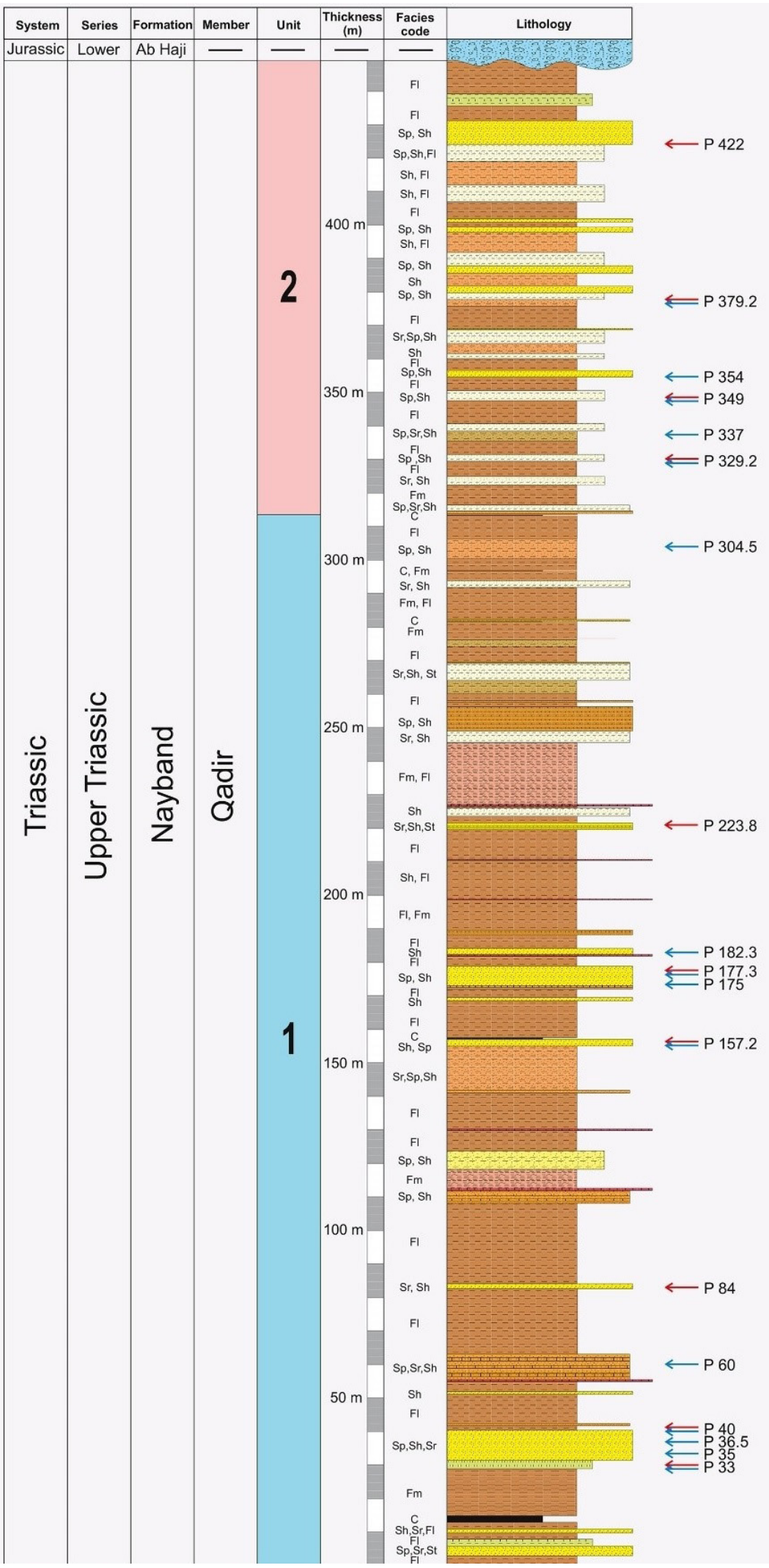

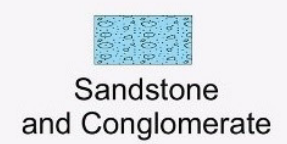

Shale and

Sandstone

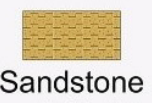

and Shale

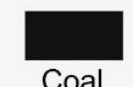

Marl and

Shale

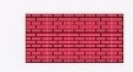

Fossiliferous

limestone

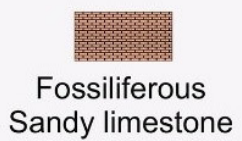

Sandy limestone

Silty shale

Sandstone

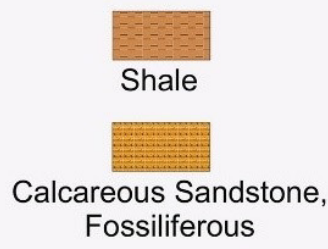

Geochemical sample location

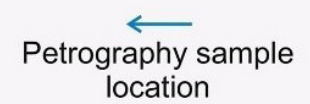

Figure 3 The lithostratigraphic column of the Qadir Member of the Nayband Formation, representing the location of samples for geochemical analysis (arrow sign). 
Its lower boundary is covered in this section and the upper boundary is disconformable with coarse-grained sediments of the Ab-Haji Formation (white sandstones and red-brown conglomerate - Early Jurassic) (Figures 2 and 3). According to lithological features, Qadir Member is divided into two.

\subsubsection{THE UNIT 1}

This unit with $315 \mathrm{~m}$ thickness consists of alternating shale sediments and light green sandstone with layers of fossiliferous limestone (brachiopod, bivalve, coral, etc.) and coal (Figure 2). The shale and marls in the unit 1 are more expanded than the unit 2, and the most important feature of the unit 1 compared to the unit 2 is the presence of numerous hematite concretions. The contact of the unit 1with the unit 2 corresponds to the last layer of coal at the top of the unit 1 . The most prominent feature of this unit is the presence of a wide range of trace fossils such as Thalassinoides, Rhizocorallium, Planolites, Skolithos, Scolicia, Arenicolites, etc. along with abundant plant fossils and sedimentary structures such as symmetrical ripple mark to asymmetrical ripple mark, herringbone, planar cross-bedding, lamination, trough cross-bedding, ripple cross-bedding, convolute bedding (Figure $4 \mathrm{a}, 4 \mathrm{~b}, 4 \mathrm{c}, 4 \mathrm{~d}, 4 \mathrm{e}$ and $4 \mathrm{f}$ ) and will be discussed in detail in the facies and sedimentary environment analysis.

\subsubsection{THE UNIT 2}

This unit has a thickness of 185 meters and, similar to unit 1 , is composed of alternating shale and green sandstone (Figure 4g). The most distinctive features of this unit compared to unit 1 are the absence of coal layers and fossiliferous limestones as well as fewer fossil traces. The unit is often in the form of badland and steep slope walls in the field (Figure 4h).

\subsection{FACIES ANALYSIS}

Based on the field studies and evidence as well as the modified lithofacies classifications of Miall (2000, 2006) along with the analysis of lithofacies, Qadir Member is composed of siliciclastic and carbonate facies. Siliciclastic facies were identified, consisting

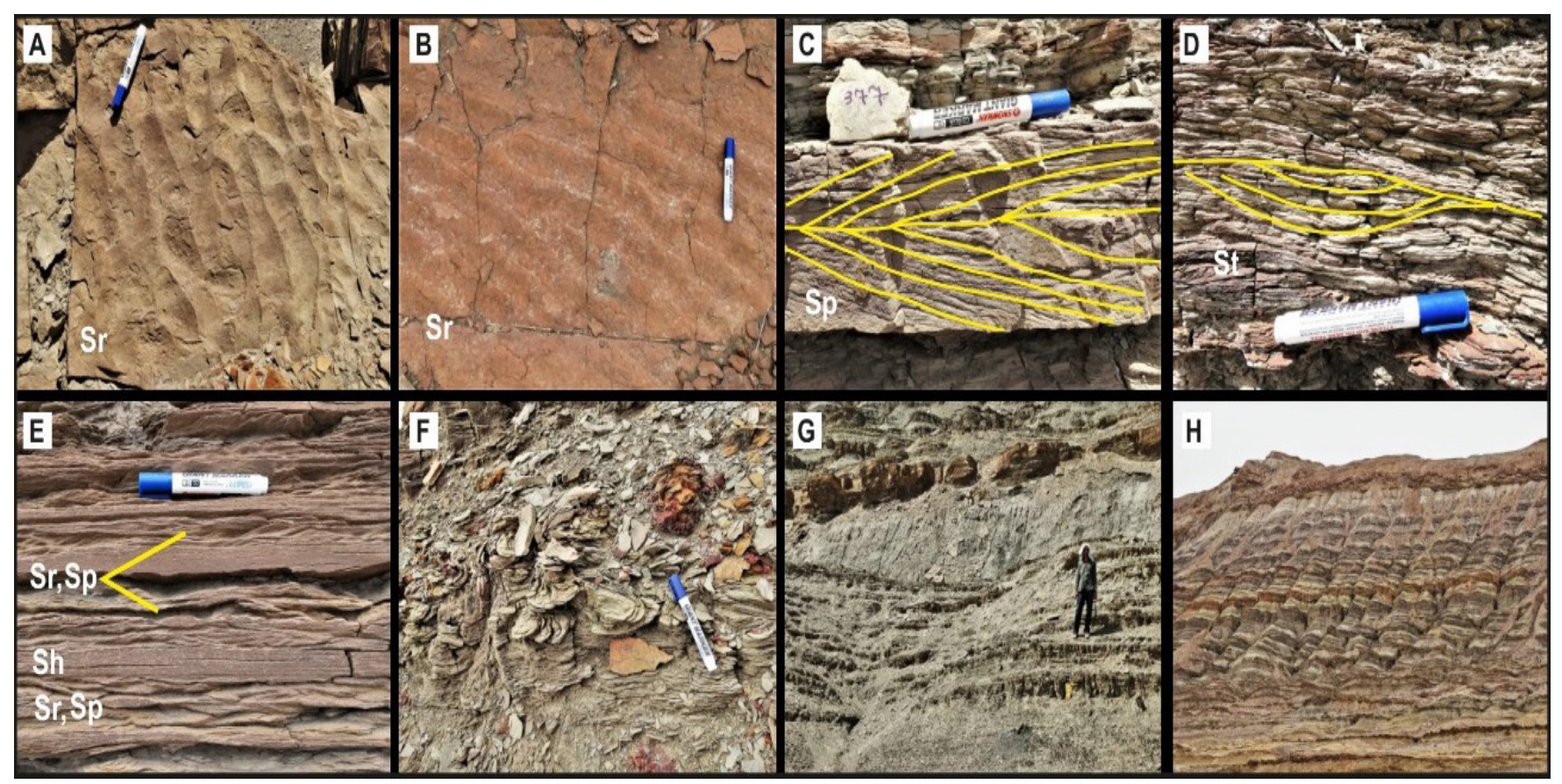

Figure 4 A-B) symmetrical to asymmetrical ripple mark, C) herringbone, D) trough cross bedding and lamination, E) ripple cross bedding ( $\mathrm{Sr}$ and $\mathrm{Sp}$ ) and horizontal lamination (Sh), F) convolute bedding, G) shale and sandstone alternation in the unit $2, \mathrm{H}$ ) general view and badland and steep slope walls of unit 2. 
of four sandstone facies including Sr, Sh, Sp and St and three fine- grain facies comprising of $\mathrm{Fl}$ and $\mathrm{Fm},(\mathrm{Sr}) \mathrm{Fl} /(\mathrm{Fl}) \mathrm{Sr}$ along with a coal-based $(\mathrm{C})$ facies and carbonate facies including calcirudite and calcirudite (Table 1). Sandstone thin sections were also at a range of sub mature to mature and litharenite to sublitharenite petrofacies in terms of maturity (Figures 5a, 5b, 5c and 5d).

\subsubsection{SANDSTONE FACIES ASSOCIATION}

Medium grain lithofacies were of relatively high abundance and four sandstone facies of $\mathrm{Sr}, \mathrm{Sh}, \mathrm{Sp}$, and St were identified. These facies were classified by sedimentary structures and show relatively uniform similarities in texture and lithological characteristics.
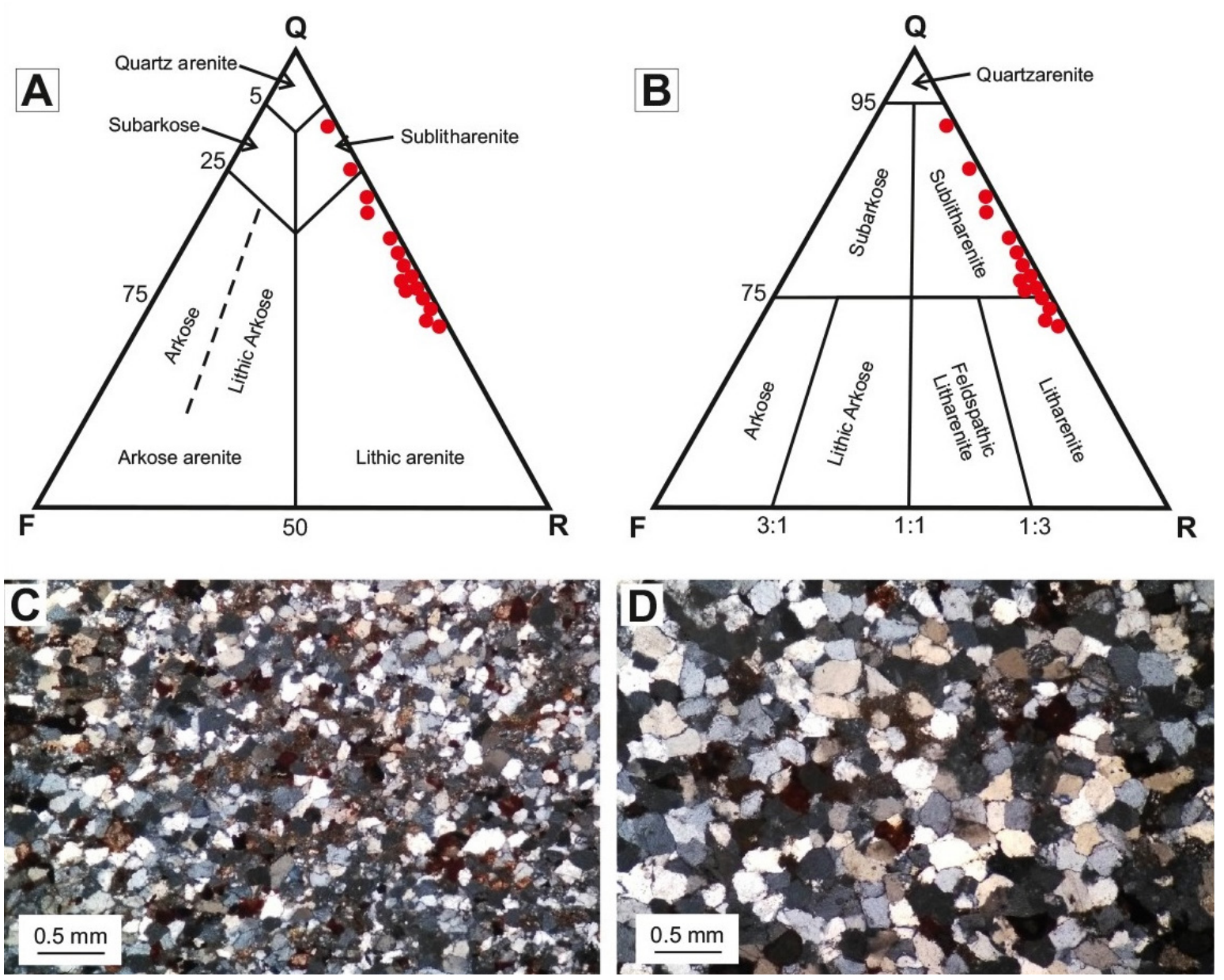

Figure 5 A-B) Mineralogical classification of the sandstones from Qadir Member in the Pettijohn et al., 1987 and Folk (1980) diagrams (Q: total quartz; F: feldspar; R: rock fragment), C) litharenite, D) sublitharenite.

\subsubsection{RIPPLED LAMINATION AND LAYERED SANDSTONE FACIES (SR)}

Rippled sandstone facies is one of the identified and well-known facies of Qadir Member and shows a relatively high abundance. The size of the sandstones varies mainly from fine to medium grains, and the sandstones show moderate to good roundness and sorting, being sub mature and composed of sublitharenite petrofacies. The main characteristic of this lithofacies is the presence of various forms of symmetrical and asymmetric ripple marks with straight and sinusoidal ridges (Figure 6a). These types of ripple marks are known as indicators of coastal environments formed under different flow regime conditions (Longhitano et al., 2012). Also, direct-ridged ripple 
Table 1. Summary of characteristics and interpretation of sedimentary lithofacies (lithofacies codes modified after Miall; 2000, 2006).

\begin{tabular}{|c|c|c|}
\hline Lithofacies & Code & Description; bedding features \\
\hline \multicolumn{3}{|l|}{ Sandstone } \\
\hline Rippled & $\mathrm{Sr}$ & $\begin{array}{l}\text { Medium sand: set thickness } \\
\text { solitary or grouped, } 2-20 \mathrm{~cm} \text {, } \\
\text { sometimes with trace fossils }\end{array}$ \\
\hline $\begin{array}{l}\text { Horizontally } \\
\text { bedded or } \\
\text { laminated }\end{array}$ & Sh & $\begin{array}{l}\text { Medium-fine sand: set thickness } \\
\text { generally, } 1-200 \mathrm{~cm} \text {; sometimes } \\
\text { with trace fossils and planet } \\
\text { fossils }\end{array}$ \\
\hline $\begin{array}{l}\text { Planar cross- } \\
\text { bedded }\end{array}$ & $\mathrm{Sp}$ & $\begin{array}{l}\text { Medium sand: solitary or } \\
\text { grouped, set thickness generally } \\
\text { 3-40 cm, planar and herringbone } \\
\text { cross-bedding }\end{array}$ \\
\hline $\begin{array}{l}\text { Trough cross- } \\
\text { bedded }\end{array}$ & $\mathrm{St}$ & $\begin{array}{l}\text { Medium sand: solitary, set } \\
\text { thickness generally } \\
3-10 \mathrm{~cm}\end{array}$ \\
\hline \multicolumn{3}{|l|}{$\begin{array}{l}\text { Fine-grained (fine } \\
\text { sand, silt, clay) }\end{array}$} \\
\hline $\begin{array}{l}\text { Laminated or } \\
\text { rippled }\end{array}$ & $\mathrm{Fl}$ & $\begin{array}{l}\text { Often silt and very fine sand } \\
\text { size: } 1-2 \mathrm{~cm} \text { layers, set } \\
\text { thickness generally } \\
1-200 \mathrm{~cm} \text {, sometimes with } \\
\text { planet fossil debris }\end{array}$ \\
\hline Massive & Fm & $\begin{array}{l}\text { Often clay and very silt size: } 5- \\
\qquad 1500 \mathrm{~cm}\end{array}$ \\
\hline
\end{tabular}

Coal

\begin{tabular}{l|l|l} 
Massive & C & Coal and coaly mud: $5-250 \mathrm{~cm}$
\end{tabular} layers, with plant fossil

Interbedded sandstone and finegrained

Laminated and wavy bedded

\section{Carbonate}

Fossiliferous limestone
Rippled sand interbeds in mud

Siltstone, litharenite

Bioclast grainstone, and sometimes sandy bioclast grainstone,
Coarse-medium size: fossiliferous limestone, $5-25 \mathrm{~cm}$ layers
Interpretation; sedimentary processes

Deposition from traction current: ripple with low indices (5-7) related to wave-induced currents in tidal flat

Planar bed lower and upper flow in tidal flat: deposited under the condition of either upper or lower flow regime

Transverse and linguoid

Litharenite and sometimes sublitharenite

Siltstone - claystone

Deposition from traction current in upper intertidal and proximal delta front

Deposition from suspension on top of sandy bedforms and/or across low relief, abandoned flood plains and distal delta front

Coastal or flood plain swamp deposit with input of clastic sediment

Alternation strong and weak flows in intertidal 
marks are indicators of tidal-flow performance, reflecting the performance of marine and river processes (tide and wave) along with bifurcated ripple marks (Dalrymple et al., 1992).

\subsubsection{HORIZONTAL LAMINATION AND SANDSTONE $\operatorname{BEDS}(\mathrm{SH})$}

One of the most important features of Qadir Member is the presence of bedding and laminations horizontally. These facies are thin layers and very delicate laminations that form an association of layers with a thickness of several centimeters up to two meters (Figure 6b) and many traces of plant remnants are visible among their layers. The grain size varies from very fine to medium sand, with relatively good roundness and sorting, textural maturity from sub mature to mature with petrofacies at a range of litharenite to sublitharenite. This lithofacies could have been formed under high and low flow regimes (Lee and Chough, 2006) and laterally transformed into Sr and Sp lithofacies.

\subsubsection{PLANAR GROSS-BEDDED AND HERRINGBONE SANDSTONE FACIES (SP)}

The most prominent sandstone facies identified is lithofacies along with planar cross- bedding and
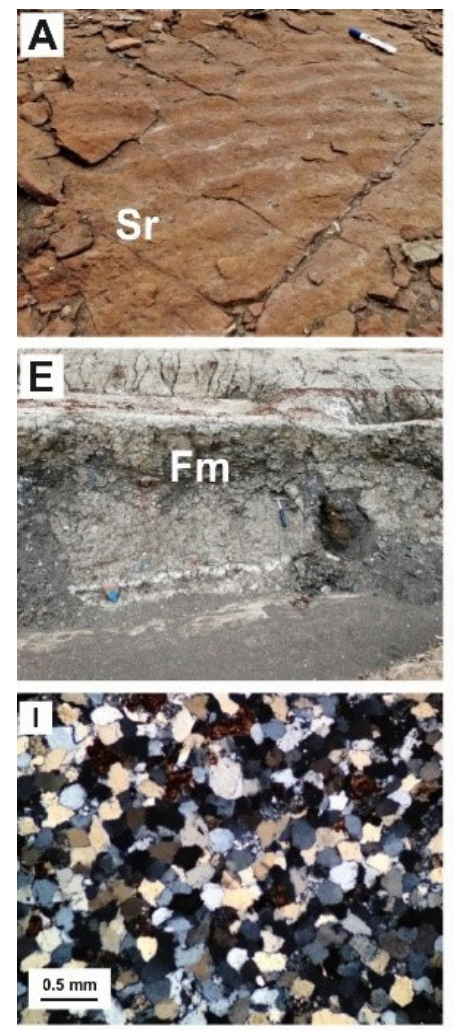
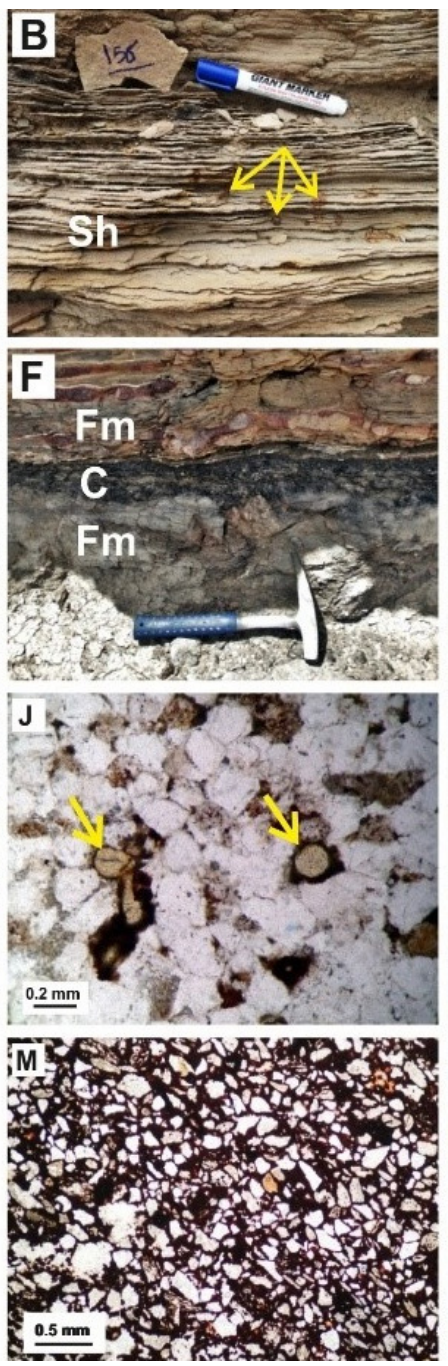
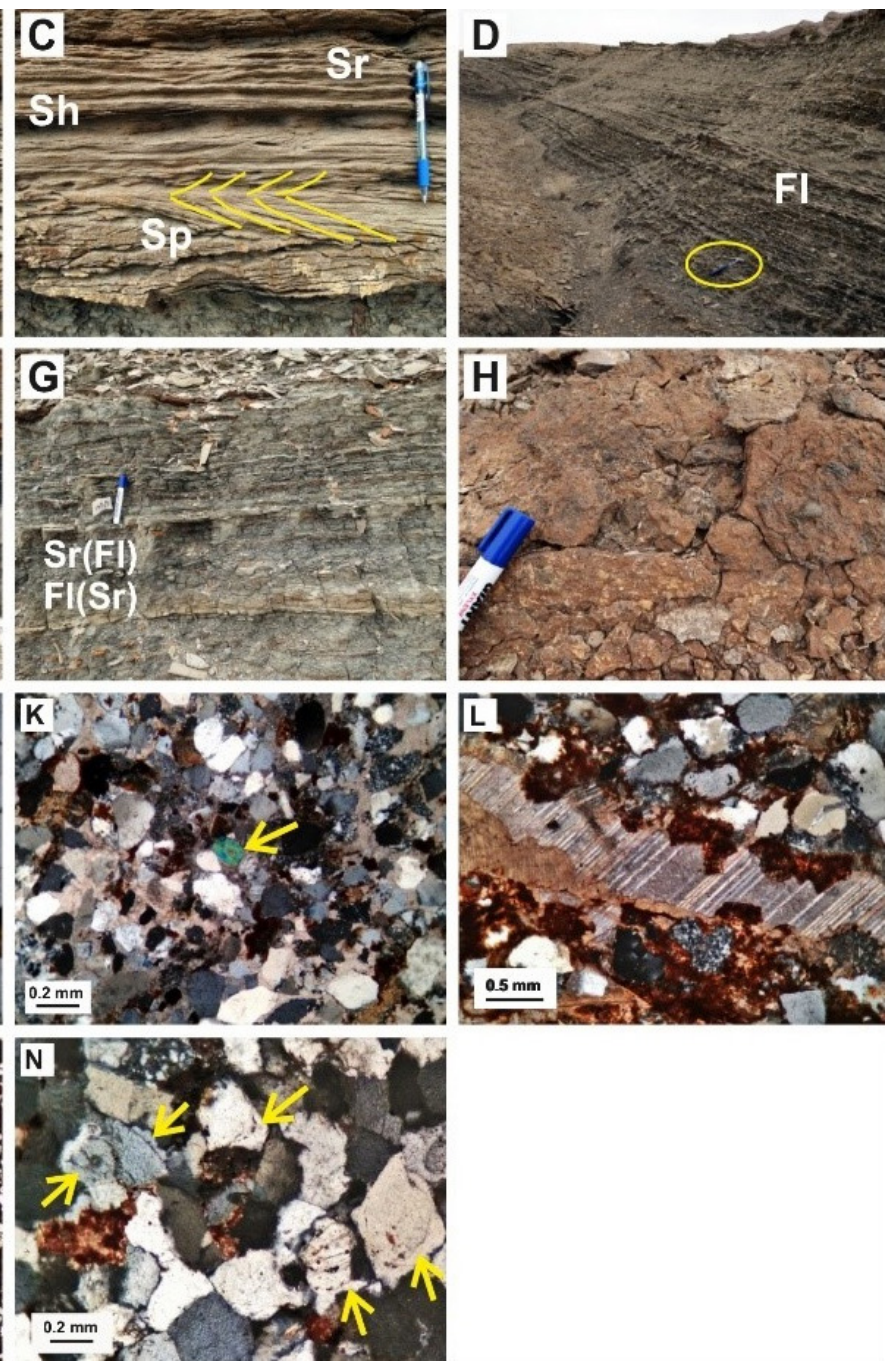

Figure 6 A) Sr lithofacies with asymmetrical ripple mark in the sandstone, B) Beds of horizontal and laminated sandstone (Sh) with hematite pebble, C) Sp lithofacies with herringbone cross-bedding, horizontal and ripple lamination, D) FI lithofacies, E) Fm lithofacies, F) C lithofacies with erosional surface and Fm lithofacies, G) Sr (FI) / FI (Sr) lithofacies, H) Carbonate lithofacies. I) Moderately sorted with convex and concave contact between sand grains, J-K) Heavy mineral include of zircon and tourmaline, L-M-N) Calcite, hematite, and silica cement types, respectively. 
herringbone (Figure 6c), related with $\mathrm{Sr}$, Sh, and Sp sandstone facies. This lithofacies represents sedimentation in one-directional and bi-directional environments (Tucker, 2001; Longhitano et al., 2012; Davis, 2012). Grains of this facies vary from fine-grained to coarse-grained and are mainly formed under low-flow regime conditions and have been described by mega ripples as well as 2-D ripples (Harms et al., 1982; Therrien, 2006). Cross beddings show angles between 5 and 15 degrees, and their grain sizes range from fine to medium sand, having relatively good roundness and sorting in terms of textural maturity, ranging from sub mature to mature. The petrofacies of this lithofacies vary from litharenite to sublitharenite. The presence of herringbones in this lithofacies indicates deposition in an environment with the oscillatory flow, especially the tidal flat zone (Strand, 2005).

\subsubsection{TROUGH CROSS-BEDDED SANDSTONE FACIES} (ST)

This lithofacies is less abundant than other facies and can be only visible to a limited extent in the first layers of unit 1 . Trough cross-bedding was observed up to $10 \mathrm{~cm}$ with fine to medium grain size. Texturally, this facies shows moderate to relatively good roundness and sorting, while it is relatively mature in composition and is related to $\mathrm{Sr}$ and Sh lithofacies. This lithofacies is characteristic of migration of 3-D ripples and mega ripples with sinuous and complex crests (Lee and Chough, 2006).

\subsubsection{FINE GRAINED FACIES ASSOCIATION (MUDSTONE FACIES)}

The fine-grained lithofacies are often present in the lower and middle parts of Qadir Member and comprise approximately $50 \%$ of the studied
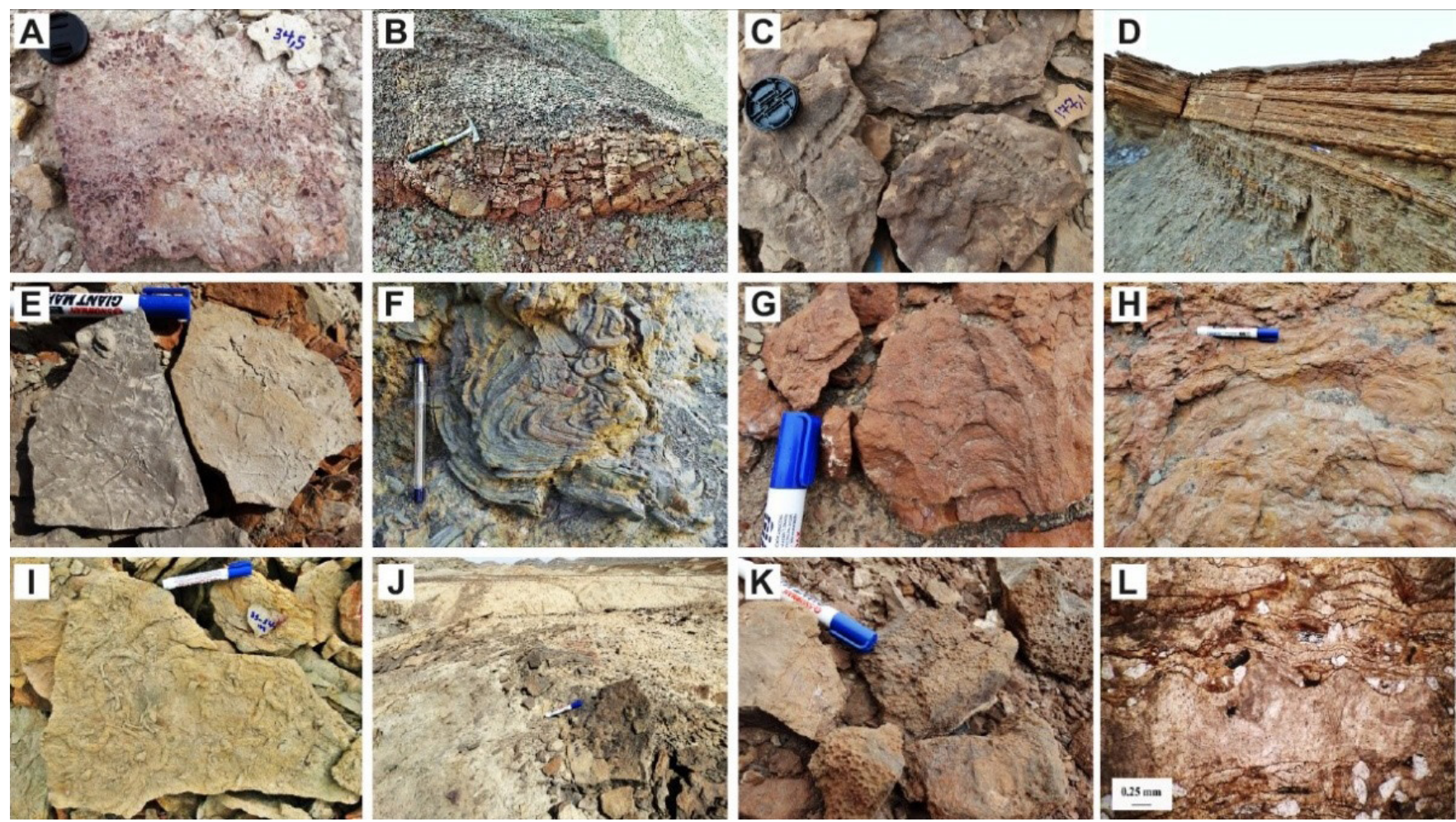

Figure 7 A) Bivalve fossil fragments impregnated with iron oxide in coastal plain sandstone, B) Tidal channel in the coastal plain part, C) Arenicolites trace fossil, D) Coarsening upward cycles of silty shale and sandstone in the proximal delta front along with planar cross-bedding and herringbone, symmetrical and asymmetrical ripple mark and planet fossil fragments, E) Planolites trace fossil along with symmetrical ripple mark in the proximal delta front, F) Convolute bedding in sandstones intercalation of proximal delta front, G-I) Rhizocorallium jenese, rhizocorallium irregular and thalassinoides trace fossils in the proximal delta front, J) Fine-grain sediments (marl and silty shale) with thin layers of fossiliferous limestones in the prodelta and open marine, K) Coral pieces, L) Sandy bioclast grainstone facies. 
sequence. Three silty and mud fine-grained lithofacies with laminations $(\mathrm{Fl})$, without laminations $(\mathrm{Fm})$ and coal $(\mathrm{G})$ were identified in the studied sequence (Figure 6d, 6e and 6f).

\subsubsection{FINE-GRAINED (FINE SAND, SILT, GLAY), LAMINATED MUD (FL)}

This mudrock facies is composed of fine-grains, which are mainly silt to clay-sized, mostly formed under low-water conditions and as a result of suspended currents (Higgs et al., 2012). This lithofacies is visible in parts of Qadir Member with very fine-grained sand to silt (Figure 6d). The presence of very fine and parallel laminates is one of the most important features of this lithofacies, which is often blackish dark green in color, and in some cases convolute bedding is also clearly visible. The green color of this facies indicates its formation in anoxic conditions (for example: Davis, 2012).

\subsubsection{FINE-GRAINED (FINE SILT, CLAY), MASSIVE MUD (FM)}

This facies is blackish dark green without any stratification, with its thickness reaching over $15 \mathrm{~m}$ in Qadir Member, and seen with Fl and C lithofacies (Figure 6e). The presence of these facies along with other fine-grained and coal lithofacies indicates the rapid deposition of suspended particles in water and in a low-energy environment such as floodplains in deltaic and river environments affected by low gravity currents (Miall, 2006).

\subsubsection{COAL FACIES (C)}

This facies is in the form of a coal layer varying from a few centimeters to about 2 meters and is observed along with the $\mathrm{Fl}$ and $\mathrm{Fm}$ facies, having very high organic matter and dark color in the field (Figure 6f). Coals (coal facies) are generally interpreted as an integral part of the floodplain sequence in deltaic and river environments (Miall, 2006).

\subsubsection{FINE GRAINED FACIES ASSOCIATION OF SANDSTONE}

Based on the field studies and evidence, two different lithofacies including ( $\mathrm{Fl}) \mathrm{Sr} /(\mathrm{Sr}) \mathrm{Fl}$ fall into this group. These facies have been identified spo- radically in different parts of the Qadir Member (Figure 6g). In fact, the facies association is formed by changes in energy levels within sedimentary systems. Therefore, intercalated sandstones (at high energy time) and mudrock facies (at low energy time) will be formed. Accordingly, in a short time and low energy conditions, fine-grained Fl lithofacies are attached to the ripples and vice versa at longer times and increased flow energy, coarse-grained sandstone sediments will be deposited above the mud fine-grained sediments, forming these lithofacies (Longhitano et al., 2012; Zamaniyan et al., 2018).

\subsubsection{GARBONATE LITHOFACIES}

These lithofacies in the field vary in layers from several centimeters to less than $1 \mathrm{~m}$ thickness and include fossiliferous limestones (containing bivalve, brachiopod, coral, gastropod, echinoderm, etc.) and sandy fossiliferous limestone with a color of reddish-brown (Figure 6h). These calcareous layers are laterally reduced in thickness and removed.

\subsection{PETROGRAPHY}

As stated above, Qadir Member in the studied area consists mainly of shale and sandstones with intercalations of limestone and coal. Petrographic studies of 86 thin sections show that the sandstone samples are often fine to coarse-grained, sub angular to sub rounded, poorly to moderately sorted with convex and concave contact between sand size grains (Figure 6i). The amount of clay in these samples is low and in terms of maturity, they are sub mature to mature. The components of sandstones include different types of monocrystalline and polycrystalline quartz (including 2 or 3 , and more than 3 components), plagioclase, and various types of sedimentary rock fragments (chert and sandstone) and a few metamorphic fragments. Accessory minerals are mica and heavy minerals such as zircon and tourmaline (Figures $6 \mathrm{j}$ and $6 \mathrm{k}$ ) with very insignificant frequency (less than one percent). Calcite, hematite, and silica are the most frequent cement types, respectively (Figures 
Table 2. Framework parameters of detrital modes (Ingersoll and Suczek, 1979).

\begin{tabular}{|c|c|}
\hline Qm non & $\begin{array}{c}\text { Non-undulouse monocrystalline quartz } \\
\text { Undulouse monocrystalline quartz }\end{array}$ \\
\hline Qm un & Polycrystalline quartz \\
\hline Qpq & Qpq2-3 crystal units per grain \\
\hline Qpq2-3 & Qpq $>3$ crystal units per grain \\
\hline Qpq $>3$ & Chert \\
\hline Cht &
\end{tabular}

\begin{tabular}{|c|}
\hline Qp \\
\hline $\mathbf{Q t}$ \\
\hline $\mathbf{Q}$ \\
\hline $\mathbf{P}$ \\
\hline $\mathbf{K}$ \\
\hline $\mathbf{F}$ \\
\hline $\mathbf{L v}$ \\
\hline $\mathbf{L s}$ \\
\hline $\mathbf{L s m}$ \\
\hline $\mathbf{L c}$ \\
\hline $\mathbf{L}$ \\
\hline $\mathbf{L t}$ \\
\hline $\mathbf{R F}$ \\
\hline
\end{tabular}

Polycrystalline quartzose (or calcedonic) lithic fragments (Qpq + Cht)

Total quartzose grains (Qm + Qp)

Total (Qm non + Qm un) and Qpq used for classification (Qm + Qpq) (Folk, 1974)

plagioclase feldspar

Potassium feldspar

Total feldspar grains $(\mathrm{P}+\mathrm{K})$

Volcanic-metavolcanic rock fragments

Sedimentary rock fragments

Metasedimentary rock fragments

Carbonate (reworked fossils and limeclasts include mudstone) rock fragments

Unstable (siliciclastic) lithic fragments $(\mathrm{Lv}+\mathrm{Ls}+\mathrm{Lsm})$

Total siliciclastic lithic fragments $(\mathrm{L}+\mathrm{Qp})$

Total unstable rock fragments and chert $(\mathrm{L}+\mathrm{Cht})($ Folk, 1974 classification)

61, 6m, and 6n). Also, given that Qadir Member sandstones have very low clay content, based on the diagrams of Pettijohn et al., 1987 and Folk (1980) and according to the data plot from modal analysis (Table 2 and 3), sandstone samples are at a range of litharenite to sublitharenite (Figures $5 \mathrm{a}$, $5 b, 5 c$, and $5 d$ ).

\subsection{SEDIMENTARY ENVIRONMENT}

Lithofacies are controlled by sedimentary processes that operate in specific sedimentation environments, while changes in flow regimes result in altered sedimentary environments and the formation of lithofacies based on the conditions prevailing in the sedimentary basin; hence, recognition of lithofacies contributes significantly to the interpretation of synsedimentation (Kumar et al., 2007; Catuneanu, 2003). Analysis of the facies identified in Qadir Member led to the identification of three facies associations of coastal, deltaic and marine. Coastal facies include coastal plain, while deltaic facies include 1- Delta plain,
2- Proximal delta front, 3- Distal delta front, and 4- Prodelta, and finally, marine facies include the open marine environment, which will be discussed in more detail below.

\subsubsection{COASTAL PLAIN}

Description: This facies association is composed of medium to slightly coarse grains with thin to medium sandstone layers of 4 to $9 \mathrm{~m}$ thickness, showing a fining upwards. The sedimentary structures of this section consist mainly of symmetrical ripple marks, herringbone cross-bedding, and horizontal laminations with some of the bivalve fossil fragments and plant particles. This facies is visible in the field as white to light gray to a slightly lighter green color with fossil traces of Arenicolites and Scolicia. Its most significant features are tidal channels with a depth of $0.4 \mathrm{~m}$ and a width of 1.2 $m$ with erosional base.

Interpretation: Medium to the moderately coarse-grained fabric of these sediments with moderate to good rounding and sorting along with 
Table 3. Modal analysis data and detrital modes of 15 selected sandstone samples from Qadir Member of the Nayband Formation.

\begin{tabular}{|c|c|c|c|c|c|c|c|c|c|c|c|c|c|c|c|}
\hline $\begin{array}{c}\text { Sample } \\
\text { No. }\end{array}$ & $\begin{array}{c}\mathbf{P} \\
33\end{array}$ & $\begin{array}{c}\mathbf{P} \\
\mathbf{3 5}\end{array}$ & $\begin{array}{c}P \\
36.5\end{array}$ & $\begin{array}{l}P \\
40\end{array}$ & $\begin{array}{l}P \\
60\end{array}$ & $\begin{array}{c}P \\
157.2\end{array}$ & $\begin{array}{c}P \\
175\end{array}$ & $\begin{array}{c}P \\
177.3\end{array}$ & $\begin{array}{c}P \\
182.3\end{array}$ & $\begin{array}{c}P \\
304.5\end{array}$ & $\begin{array}{c}\mathbf{P} \\
329.2\end{array}$ & $\begin{array}{c}\mathbf{P} \\
\mathbf{3 3 7}\end{array}$ & $\begin{array}{c}\mathbf{P} \\
349\end{array}$ & $\begin{array}{c}\mathbf{P} \\
354\end{array}$ & $\begin{array}{c}\mathbf{P} \\
379.2\end{array}$ \\
\hline Qm non & 171 & 82 & 188 & 160 & 68 & 17 & 65 & 22 & 25 & 74 & 98 & 62 & 103 & 73 & 53 \\
\hline Qpq & 0 & 0 & 6 & 0 & 7 & 10 & 8 & 0 & 11 & 5 & 0 & 0 & 0 & 0 & 0 \\
\hline Qpq 2-3 & 7 & 10 & 0 & 40 & 17 & 27 & 35 & 19 & 20 & 11 & 20 & 0 & 11 & 16 & 12 \\
\hline $\mathbf{Q p q}>3$ & 0 & 3 & 8 & 12 & 9 & 17 & 13 & 17 & 0 & 4 & 0 & 0 & 0 & 0 & 0 \\
\hline Cht & 59 & 28 & 26 & 21 & 35 & 25 & 75 & 49 & 42 & 43 & 37 & 45 & 27 & 41 & 39 \\
\hline Qp & 59 & 28 & 32 & 21 & 42 & 35 & 83 & 49 & 53 & 48 & 37 & 45 & 27 & 41 & 39 \\
\hline Qt & 230 & 110 & 220 & 181 & 110 & 52 & 148 & 71 & 78 & 122 & 135 & 107 & 130 & 114 & 92 \\
\hline $\mathbf{Q}$ & 230 & 110 & 226 & 181 & 117 & 62 & 156 & 71 & 89 & 127 & 135 & 107 & 130 & 114 & 92 \\
\hline $\mathbf{P}$ & 2 & 3 & 2 & 10 & 5 & 4 & 4 & 7 & 0 & 6 & 0 & 2 & 3 & 5 & 4 \\
\hline RF & 105 & 35 & 41 & 85 & 78 & 65 & 141 & 65 & 117 & 121 & 95 & 115 & 125 & 120 & 93 \\
\hline $\mathbf{L t}$ & 66 & 28 & 39 & 21 & 49 & 41 & 83 & 53 & 53 & 48 & 37 & 45 & 27 & 52 & 48 \\
\hline $\mathbf{L}$ & 7 & 0 & 7 & 0 & 7 & 6 & 0 & 4 & 0 & 0 & 0 & 0 & 0 & 11 & 9 \\
\hline Lc & 0 & 0 & 0 & 0 & 0 & 0 & 0 & 0 & 0 & 0 & 0 & 0 & 0 & 0 & 0 \\
\hline Lsm & 7 & 0 & 7 & 0 & 7 & 6 & 0 & 4 & 0 & 0 & 0 & 0 & 0 & 11 & 9 \\
\hline Ls & 0 & 0 & 0 & 0 & 0 & 0 & 0 & 0 & 0 & 0 & 0 & 0 & 0 & 0 & 0 \\
\hline Lv & 0 & 0 & 0 & 0 & 0 & 0 & 0 & 0 & 0 & 0 & 0 & 0 & 0 & 0 & 0 \\
\hline $\mathbf{F}$ & 2 & 3 & 2 & 10 & 5 & 4 & 4 & 7 & 0 & 6 & 0 & 2 & 3 & 5 & 4 \\
\hline $\mathbf{K}$ & 0 & 0 & 0 & 0 & 0 & 0 & 0 & 0 & 0 & 0 & 0 & 0 & 0 & 0 & 0 \\
\hline
\end{tabular}

symmetrical ripple mark sedimentary structures (Sr lithofacies), herringbone (Sp lithofacies) with a few plant and bivalve fragments at the stratified surface and the presence of the tidal channels indicate the formation of this facies in shallow sections of marginal seas as well as shallow environments (Figures $7 \mathrm{a}$ and $7 \mathrm{~b}$ ). In fact, the presence of structures such as intermittent ripples and symmetric waves that reflect reciprocal currents indicates the conditions of their formation in tidal to coastal environments (Zamaniyan et al., 2018). On the other hand, the presence of the herringbone, Scolicia, and Arenicolites traces fossil indicates their formation in the tidal flat zone (Figure 7c) so that the identification of the fossil effect of Arenicolites is strongly associated with the tidal flat zone sediments (Gingras et al., 2011).

\subsubsection{DELTA PLAIN}

Description: The deltaic facies is composed mainly of fine-grained silt and shale sediments with organic (coal) facies. The stratification of this facies is also visible as very thin horizontal and sometimes mass laminations and intercalations of thin sandstone and siltstone. The thickness of the facies of the delta plain varies from 5 to more than 15 meters and its most important feature is the presence of many plant remnants associated with the coal facies.

Interpretation: Given the existence of coal layers and their association with fine-grained mud sediments deposited as a result of suspended currents in a low-energy environment, they can be considered as sediments formed within the interdistributaries and marshes of the delta-coastal plain (Fielding and Frank, 2015; Higgs et al., 2012) (For example, the delta plains of the Mississippi and Rhine-Meus Rivers: Kosters, 1989; Bos, 2010). The presence of plant remnants and fine-grained sediments in this facies indicates that it has been formed in marshy environments with abundant vegetation, including clastic material (Zamaniyan et al., 2018).

\subsubsection{PROXIMAL DELTA FRONT}

Description: This facies is composed of several shale-silty and sandy cycles, becoming fining upwards. Sandstones in this part have mainly 
low-angle planar cross-bedding and herringbone cross-bedding, symmetrical and asymmetrical ripple marks with relatively abundant plant fragments (Figure 7d). Small scale trough cross-bedding is also present in a very limited range. The sand layer's thickness is up to $0.5 \mathrm{~m}$ and can be seen as laminating and diagonal as well as thin ripple layers with intercalations within the shale and silty shale. The trace fossils of Planolites associated with bioturbation in this assemblage were identified with low abundance (Figure 7e).

Interpretation: Location of these facies below the delta plain and also the presence of plant fossils along with relatively good roundness and sorting of sediments indicate the formation of this facies in the delta front area (Carlos and Ronland, 2008). The presence of symmetrical and asymmetrical ripple marks with straight ridge and low angle herringbone cross-bedding can be considered as performance indicators of tidal currents. Also, limited expansion of small-scale trough cross-bedding suggests that sediments have been affected by waves and environmental fluctuations (Walker and Plint, 1992). The presence of the trace fossils of Planolites along with Thalassinoides and Skolithos can also provide evidence of the proximal delta front section (Bayet-Goll and Carvalho, 2017; Zamaniyan et al., 2018).

\subsubsection{DISTAL DELTA FRONT}

Description: This part is mainly composed of shale and silty fine-grained sediments in blackish dark gray color with intercalations of sandstones to calcareous sandstone with a thickness of medium to thin and horizontal stratification along with convolute bedding (Figure 7f). Due to the high abundance of shale sediments, this part is well separated from the upper part of the delta front, which has more sandstone alternations. Trace fossils of Rhizocorallium Jenese, Rhizocorallium (Figures $7 \mathrm{~g}$ and $7 \mathrm{~h}$ ), and Thalassinoides (Figure 7i) were identified in this facies.

Interpretation: The shale-siltstone layers exhibit small-scale regular alternations in this
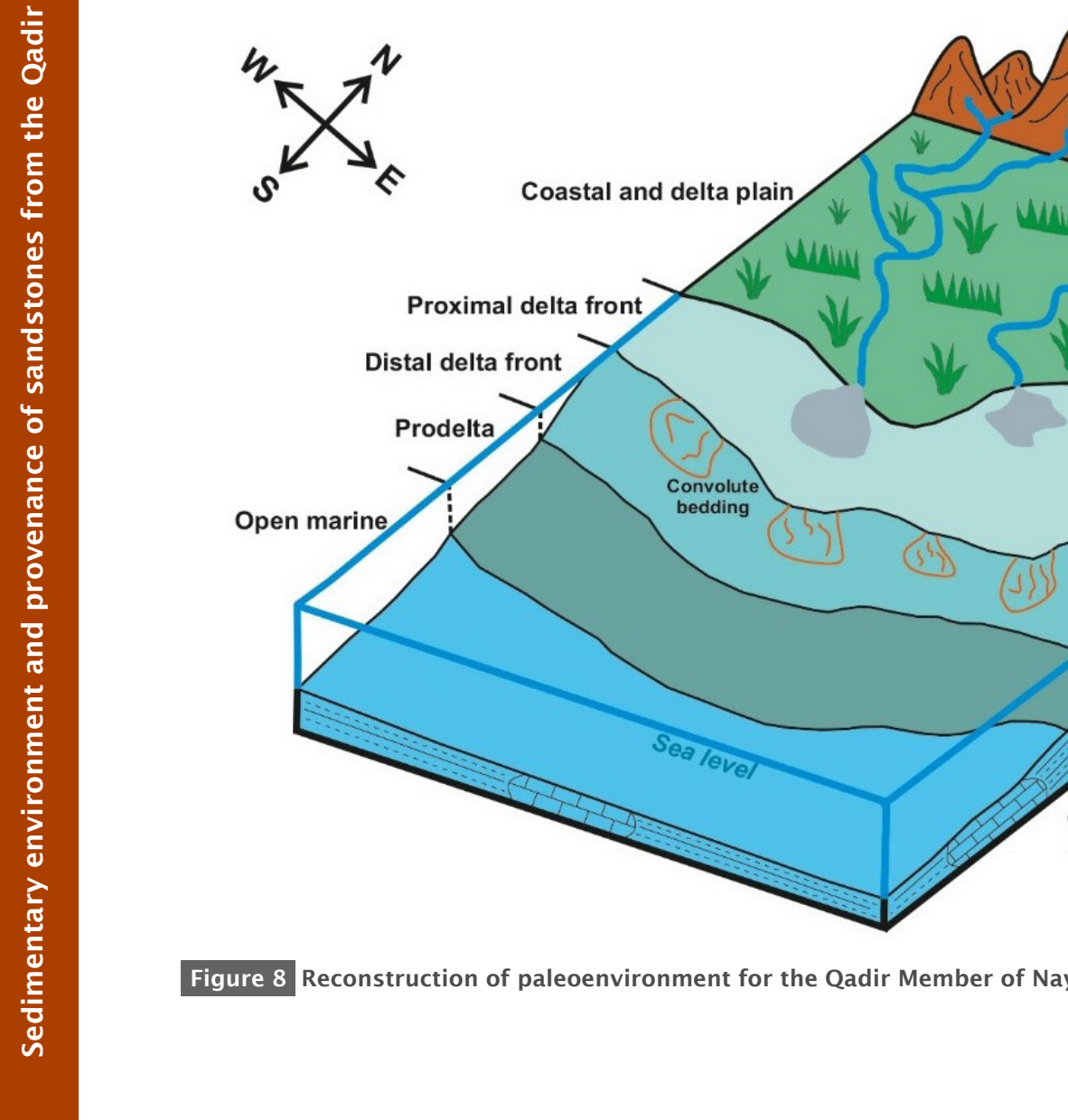

Proximal delta front

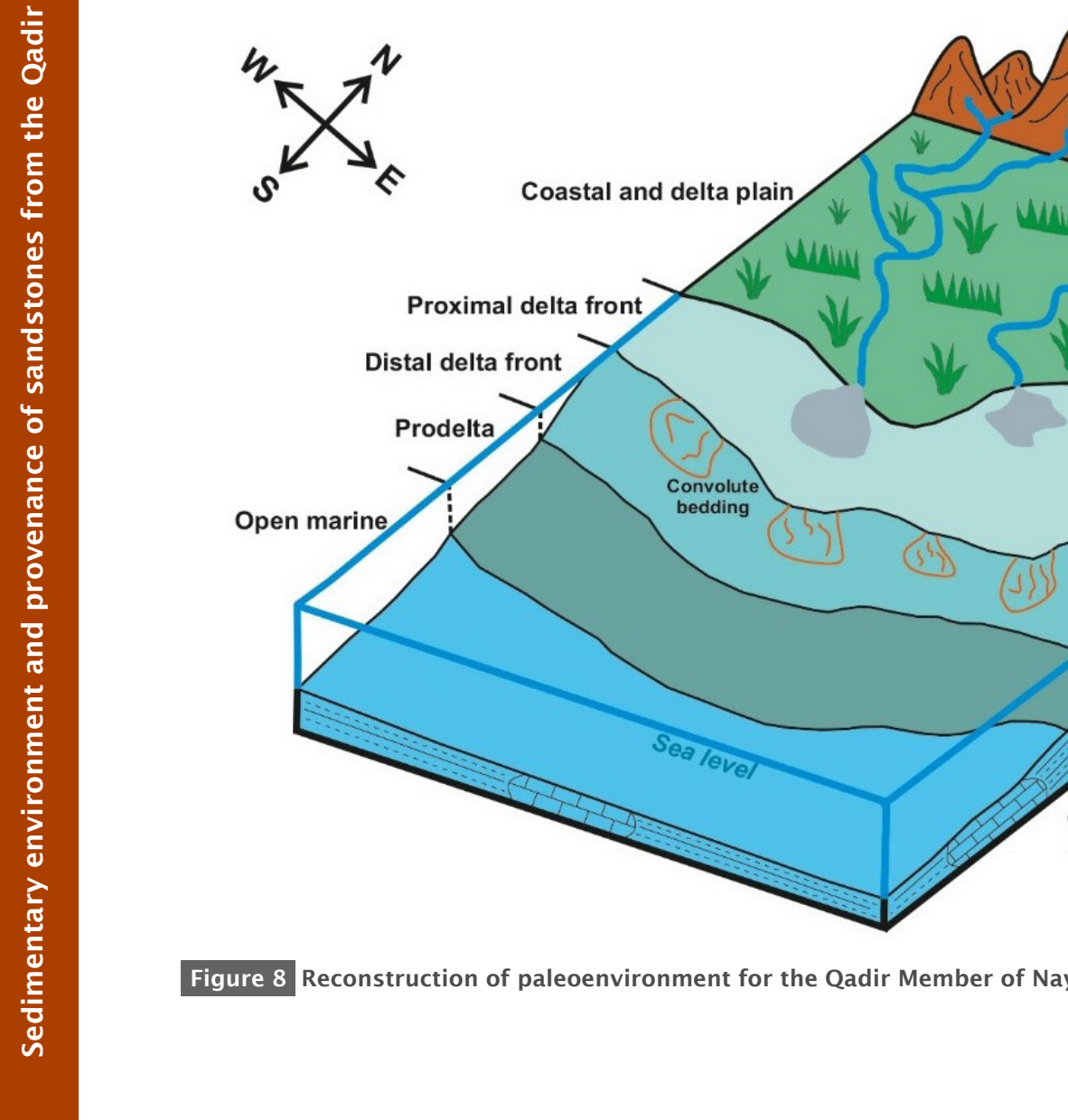


facies and, given the abundance of fine-grained sediments, the layers are well separated from the proximal delta front sediments. The presence of trace fossils of Rhizocorallium Jenese, Rhizocorallium, and Thalassinoides in this facies indicates the activity of organisms from suspended material and sedimentary bed (Bayet-Goll and Carvalho, 2017). The dominance of fine-grained sediments over the proximal delta front along with the presence of convolute bedding and scattered bioturbation indicate facies formation in the distal delta front (Fielding and Frank, 2015; Zamaniyan et al., 2018). This facies gradually changes into the final facies of the prodelta.

\subsubsection{PRODELTA}

Description: The shale-silty and marl fine-grained sediments with upward fining of the grains constitute the prodelta facies in this part and are scattered with low planar laminations that are identifiable in the unit 1 of Qadir Member (Figure $7 \mathrm{j}$ ). These sediments contain insignificant interca- lations of sandstone and thin-layer siltstone, sometimes with symmetrical ripple strata and low-angle cross bed.

Interpretation: The presence of laminar fabric, the absence of fossil evidence, and the dominance of mud sediments indicate environmental with anoxic conditions associated with low energy conditions in the deeper parts of the prodelta to open marine (Tovaglieri and George, 2014; Cotter and Dries, 1998). Also, the large volume of marl and shale sediments and their accompanying marine facies can indicate sedimentation in the prodelta during the rapid deposition of suspended particles (Einsele, 2000).

\subsubsection{OPEN MARINE}

Marine sediments of Qadir Member were identified in the 1 and 2 units (mostly unit 1), containing bioclast grainstone facies and observable along with fine-grained prodelta sediments. This facies comprises about $50-70 \%$ of the bivalve and brachiopod skeletal fragments larger than $2 \mathrm{~mm}$ in

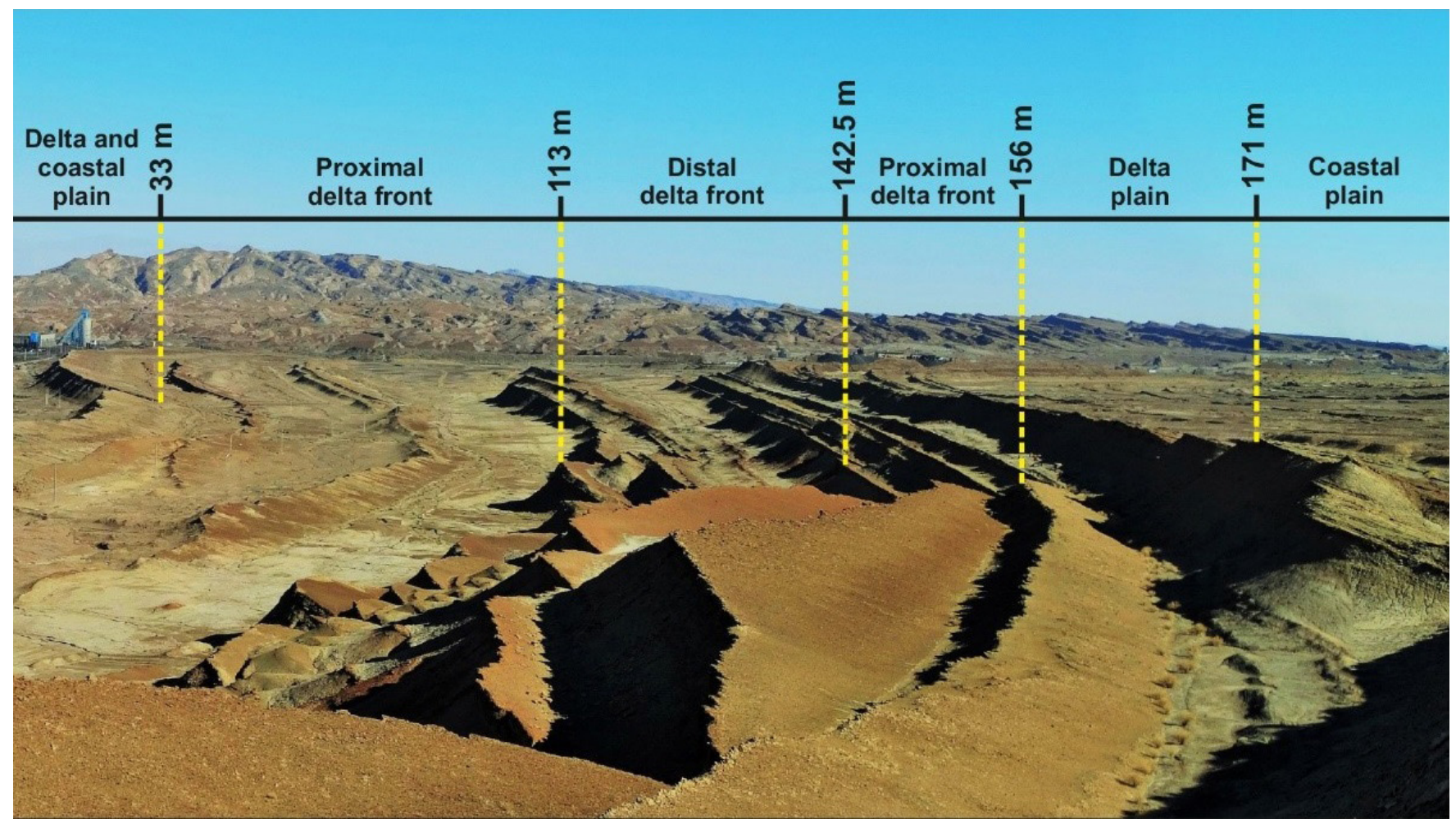


size, while other skeletal fragments (coral, echinoderm, gastropod, etc.) are less than 10\% (Figure $7 \mathrm{k}$ and l). These facies are deposited above the surface of the wave's effect in a high energy environment and belong to facies belt No. 7 and SMF1 1 Flugel (2010). The presence of grainstone facies along with very low mud and the presence of subangular siliciclastic particles (Coffey and Read, 2004) indicate formation in high-energy environments while facies with coarse-grained skeletal particles indicate shallower parts of the open marine (Flugel, 2010; Read, 1985) and facies similar to this have also been reported in the Yudova sedimentary basin, south of Montenegro (Cadjenovic et al., 2008).

Figures 8 and 9 show the proposed sedimentary model of the Qadir Member of the Nayband Formation and its various sections.

\subsection{GEOCHEMISTRY}

The results associated with the analysis of major and trace elements of sandstones in the study area are presented in Tables 4 and 5. These sandstones contain an average of $78.53 \% \mathrm{SiO}_{2}, 9.65 \% \mathrm{Al}_{2} \mathrm{O}_{3}$, $1.48 \% \quad \mathrm{Na}_{2} \mathrm{O}, 1.1 \% \mathrm{MgO}, 1.04 \% \mathrm{~K}_{2} \mathrm{O}, 0.41 \%$ $\mathrm{TiO}_{2}, 0.06 \% \mathrm{MnO}, 0.96 \mathrm{CaO}, 0.07 \% \mathrm{P}_{2} \mathrm{O}_{5}$ and $3.5 \% \mathrm{Fe}_{2} \mathrm{O}_{3}$. Also, the ratios of oxides are cal- culated and presented in Table 4: $\mathrm{SiO}_{2} / \mathrm{Al}_{2} \mathrm{O}_{3}$ (average $10.03 \%$ ), $\mathrm{K}_{2} \mathrm{O} / \mathrm{Na}_{2} \mathrm{O}$ (average $0.67 \%$ ), $\mathrm{Na}_{2} \mathrm{O}+\mathrm{K}_{2} \mathrm{O}$ (average 2.52\%), Chemical Index of Alteration or CIA (average 71.26) and Index of Compositional Variability or ICV (average $1.01 \%$ ). Based on Pettijohn's (1975) classification, sandstones include sublitharenite and slightly subarkose (Figure 10).

\section{Discussion}

\subsection{THE SOURGE ROGK TYPE}

The dominance of monocrystalline quartz grains indicates that the sediments may have been derived from a granitic source (Basu et al., 1975; Khanehbad et al., 2012a, 2012b). The source of existing silica could be often provided by the quartz, chert, feldspar, and clay minerals. The amounts of $\mathrm{Al}_{2} \mathrm{O}_{3}$ and $\mathrm{K}_{2} \mathrm{O}$ can be related to the presence of k-feldspar (microcline), mica, and clay minerals. The amount of $\mathrm{Na}_{2} \mathrm{O}$ is mainly related to Na-feldspar (albite). The amount of $\mathrm{TiO}_{2}$ is largely related to rutile, opaque minerals, and volcanic mafic rocks. $\mathrm{Fe}_{2} \mathrm{O}_{3}$ can also be related to heavy minerals and hematite cement, as well as iron oxide bearing

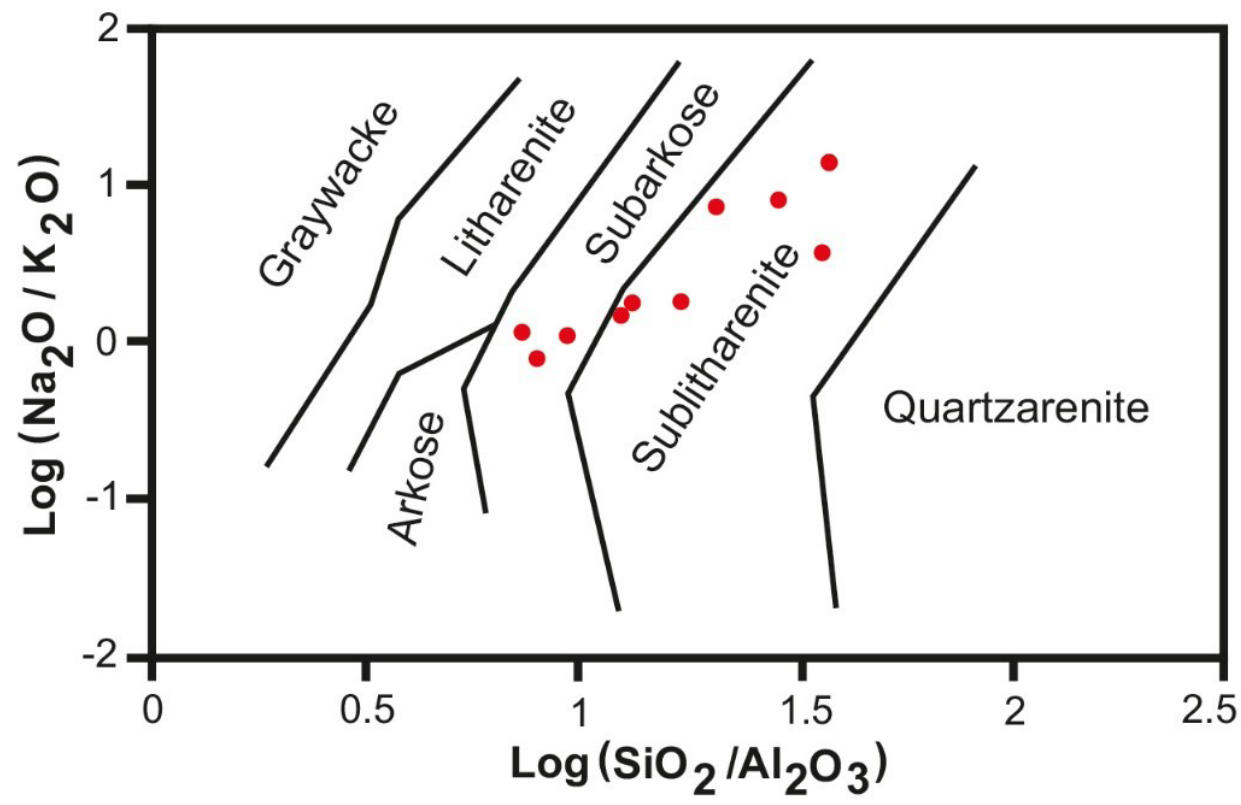

Figure 10 The chemical composition of Qadir Member sandstones plotted on the diagram (Pettijohn, 1975). 
Table 4. Major element (oxide \% wt) concentrations in the sandstones of Qadir Member (LOI: Loss of ignition, CIA: Chemical Index of Alteration, ICV: Index of Compositional Variability).

\begin{tabular}{|c|c|c|c|c|c|c|c|c|c|c|c|}
\hline $\begin{array}{c}\text { Sample } \\
\text { No. }\end{array}$ & P 33 & P 40 & P 84 & P 157.2 & P 177.3 & P 223.8 & P 329.2 & P 349 & P 379.2 & P 422 & Average \\
\hline $\mathrm{SiO}_{2}$ & 87.77 & 82.65 & 85.64 & 79.71 & 80.78 & 75.95 & 72.93 & 72.45 & 76.56 & 70.94 & 78.53 \\
\hline $\mathbf{A l}_{2} \mathbf{O}_{3}$ & 4.83 & 7.28 & 4.82 & 8.19 & 5.51 & 10.81 & 13.87 & 14.77 & 12.67 & 13.76 & 9.65 \\
\hline $\mathrm{Na}_{2} \mathrm{O}$ & 1.32 & 1.38 & 1.46 & 1.34 & 1.31 & 1.44 & 1.54 & 1.88 & 1.61 & 1.52 & 1.48 \\
\hline MgO & 0.6 & 1.21 & 0.1 & 1.45 & 1.02 & 1.34 & 1.56 & 1.35 & 1.18 & 1.19 & 1.1 \\
\hline $\mathbf{K}_{2} \mathbf{O}$ & 0.34 & 0.48 & 0.72 & 0.94 & 0.44 & 1.09 & 1.65 & 1.67 & 1.44 & 1.65 & 1.04 \\
\hline $\mathrm{TiO}_{2}$ & 0.2 & 0.22 & 0.13 & 0.43 & 0.21 & 0.5 & 0.6 & 0.69 & 0.55 & 0.59 & 0.41 \\
\hline MnO & 0.05 & 0.08 & 0.08 & 0.04 & 0.11 & 0.06 & 0.07 & 0.02 & 0.02 & 0.07 & 0.06 \\
\hline $\mathrm{CaO}$ & 0.89 & 0.94 & 1.48 & 1.19 & 3.55 & 0.34 & 0.27 & 0.15 & 0.18 & 0.66 & 0.96 \\
\hline $\mathbf{P}_{2} \mathbf{O}_{5}$ & 0.05 & 0.09 & 0.06 & 0.09 & 0.06 & 0.13 & 0.1 & 0.08 & 0.02 & 0.09 & 0.07 \\
\hline $\mathrm{Fe}_{2} \mathrm{O}_{3}$ & 2.04 & 2.99 & 2.14 & 3.61 & 2.68 & 4.98 & 4.47 & 3.89 & 3.14 & 5.09 & 3.5 \\
\hline $\mathrm{SO}_{3}$ & 0.15 & 0 & 1.82 & 0.02 & 0.15 & 0.05 & 0 & 0 & 0 & 0.01 & 0.22 \\
\hline LOI & 1.56 & 2.52 & 1.85 & 2.8 & 4.05 & 3.03 & 2.73 & 2.82 & 2.44 & 4.14 & 2.79 \\
\hline CIA & 65.44 & 72.22 & 56.83 & 70.24 & 50.97 & 79.02 & 80.03 & 79.96 & 79.68 & 78.22 & 71.26 \\
\hline ICV & 1.15 & 1.02 & 1.27 & 1.14 & 1.7 & 0.94 & 0.77 & 0.69 & 0.68 & 0.82 & 1.01 \\
\hline
\end{tabular}

Table 5. Trace element (ppm) concentrations in the sandstones of Qadir Member (Note: $\mathbf{N}=$ not detected).

\begin{tabular}{|c|c|c|c|c|c|c|c|c|c|c|c|}
\hline $\begin{array}{c}\text { Sample } \\
\text { No. }\end{array}$ & P 33 & P 40 & P 84 & P 157.2 & P 177.3 & P 223.8 & P 329.2 & P 349 & P 379.2 & P 422 & Average \\
\hline $\mathbf{R b}$ & 38 & 42 & 35 & 67 & 35 & 74 & 89 & 95 & 89 & 99 & 66.3 \\
\hline $\mathbf{B a}$ & 74 & 39 & 17 & 30 & 87 & 29 & 44 & 29 & 26 & 54 & 42.9 \\
\hline $\mathrm{Sr}$ & 112 & 147 & 130 & 130 & 145 & 106 & 134 & 127 & 120 & 143 & 129.4 \\
\hline Th & 2 & $\mathrm{~N}$ & 10 & 1 & $\mathrm{~N}$ & 6 & 11 & 13 & 16 & 11 & 7 \\
\hline $\mathbf{U}$ & $\mathrm{N}$ & $\mathrm{N}$ & 3 & $\mathrm{~N}$ & 0 & 2 & $\mathrm{~N}$ & $\mathrm{~N}$ & $\mathrm{~N}$ & $\mathrm{~N}$ & 0.5 \\
\hline $\mathbf{Y}$ & 24 & 32 & 17 & 38 & 24 & 34 & 45 & 52 & 48 & 46 & 36 \\
\hline $\mathbf{Z r}$ & 371 & 391 & 58 & 537 & 238 & 276 & 406 & 498 & 239 & 102 & 311.6 \\
\hline Nb & $\mathrm{N}$ & 2 & $\mathrm{~N}$ & 5 & $\mathrm{~N}$ & 1 & 14 & 8 & 8 & 8 & 4.6 \\
\hline $\mathbf{V}$ & 31 & 35 & 25 & 50 & 33 & 6 & 69 & 75 & 61 & 69 & 45.4 \\
\hline Co & 3 & 8 & 7 & 6 & 5 & 13 & 14 & 11 & 10 & 14 & 9.1 \\
\hline $\mathrm{Cu}$ & 199 & 203 & 184 & 97 & 36 & 103 & 131 & 132 & 146 & 101 & 133.2 \\
\hline $\mathbf{N i}$ & 16 & 36 & 23 & 60 & 47 & 48 & 50 & 50 & 57 & 62 & 44.9 \\
\hline $\mathrm{Cr}$ & 74 & 35 & 17 & 75 & 56 & 62 & 61 & 59 & 46 & 75 & 56 \\
\hline $\mathrm{Ce}$ & 38 & $\mathrm{~N}$ & 42 & 37 & 13 & $\mathrm{~N}$ & 32 & 68 & 19 & 47 & 29.6 \\
\hline Cl & 560 & 85 & 319 & 78 & 64 & 1522 & 126 & 197 & 103 & 971 & 40.25 \\
\hline $\mathbf{P b}$ & 56 & 72 & 61 & 45 & 58 & 57 & 67 & 57 & 34 & 65 & 57.2 \\
\hline $\mathrm{Zn}$ & 36 & 62 & 58 & 68 & 74 & 138 & 103 & 126 & 90 & 102 & 85.7 \\
\hline $\mathrm{V} / \mathrm{Cr}$ & 0.41 & 1 & 1.47 & 0.66 & 0.58 & 0.09 & 1.13 & 1.27 & 1.32 & 0.92 & 0.81 \\
\hline $\mathrm{Ni} / \mathrm{Co}$ & 5.3 & 4.5 & 3.2 & 10 & 9.4 & 3.69 & 3.57 & 4.54 & 5.7 & 4.42 & 4.93 \\
\hline
\end{tabular}


minerals. The amount of $\mathrm{MgO}$ is in relation to the presence of dolomite, in the form of cement, and the amount of $\mathrm{CaO}$ is largely in relation to the presence of calcite cement and skeletal fragments; the source of $\mathrm{MgO}$ and $\mathrm{CaO}$ can be provided by the carbonate particles (Khanehbad et al., 2012a, 2012b). The major elements of Qadir sandstones were compared with the upper continental crust (UCC; Taylor and McLennan, 1985) (Figure 11). According to the plotted diagram, $\mathrm{Al}_{2} \mathrm{O}_{3}, \mathrm{FeO}$, $\mathrm{MgO}, \mathrm{CaO}, \mathrm{Na}_{2} \mathrm{O}$, and $\mathrm{TiO}_{2}$ are significantly less than UCG. The depletion of $\mathrm{Na}_{2} \mathrm{O}$ can be related to the lower ratio of sodium feldspar which is corresponding to the petrography data. The very low concentration of $\mathrm{CaO}$ can depict the lack of carbonate minerals with calcium depletion during diagenetic processes (Salehi et al., 2014). In addition, the low amounts of $\mathrm{TiO}_{2}$ could be due to phyllosilicates (especially illite) in a way that the high concentration of $\mathrm{TiO}_{2}, \mathrm{CaO}, \mathrm{MgO}, \mathrm{K}_{2} \mathrm{O}$, $\mathrm{Fe}_{2} \mathrm{O}_{3}$, and $\mathrm{Al}_{2} \mathrm{O}_{3}$ means the existence of more clay phases (Dabard, 1990; Getaneh, 2002).

Considering that aluminum oxide is almost unchangeable during weathering, transformation and, diagenesis, it can be used as a factor for lithology comparisons and also comparison with other major elements (Getaneh, 2002; Akarish and El-Gohary, 2008). The amounts of $\mathrm{Al}_{2} \mathrm{O}_{3}$ versus other major oxides have been presented in Figure 12. Elements of $\mathrm{Fe}_{2} \mathrm{O}_{3}, \mathrm{~K}_{2} \mathrm{O}, \mathrm{MgO}, \mathrm{Na}_{2} \mathrm{O}$, and $\mathrm{TiO}_{2}$ show a positive trend with $\mathrm{Al}_{2} \mathrm{O}_{3}$. Compliance and frequency of these oxides with the $\mathrm{Al}_{2} \mathrm{O}_{3}$ indicate the presence of clay minerals, especially aluminosilicate (Pettijohn et al., 1987; Das et al., 2006; Khanehbad et al., 2012a, 2012b). On the other hand, $\mathrm{CaO}$ and $\mathrm{SiO}_{2}$ represent a negative trend (reverse) with the $\mathrm{Al}_{2} \mathrm{O}_{3}$. The significant point regarding $\mathrm{Al}_{2} \mathrm{O}_{3}$ and $\mathrm{SiO}_{2}$ is that by increasing the amount of $\mathrm{SiO}_{2}$, the amount of aluminum oxide (less than $5 \%$ ) decreases. This could be due to the presence of more-quartz phases and high textural maturity in the given compositions (Bayet-Goll and Hosseini Barzi, 2011). In addition, the reverse relationship of $\mathrm{CaO}$ could be referred to as the presence of diagenetic and secondary alterations of calcite (Das et al., 2006).

The trace element's pattern can be used to determining the source of sediments and present

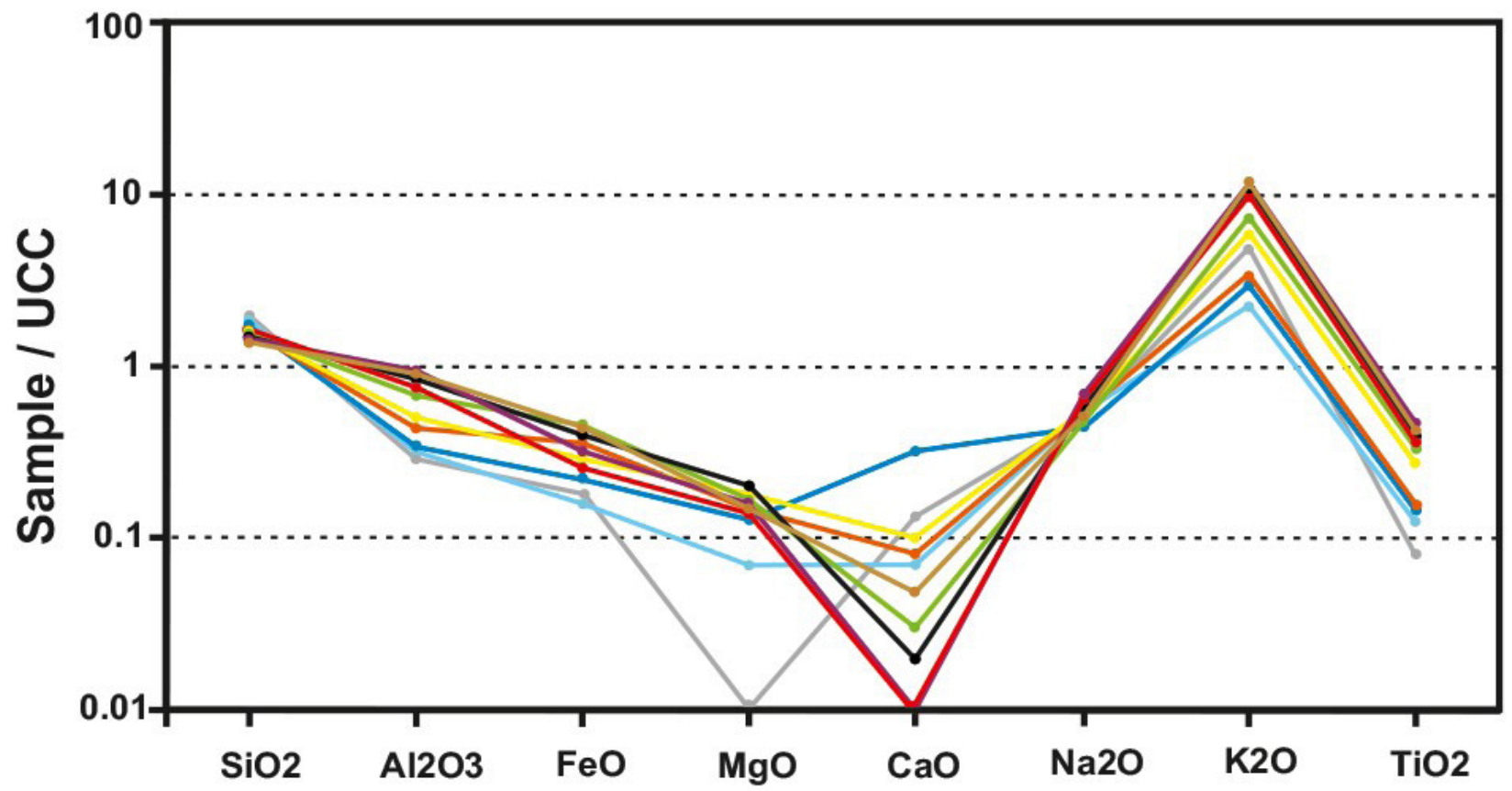

Figure 11 Normalization of major oxides of Qadir Member sandstones in comparison with the upper continental crust (UCC; Taylor and McLennan, 1985). 

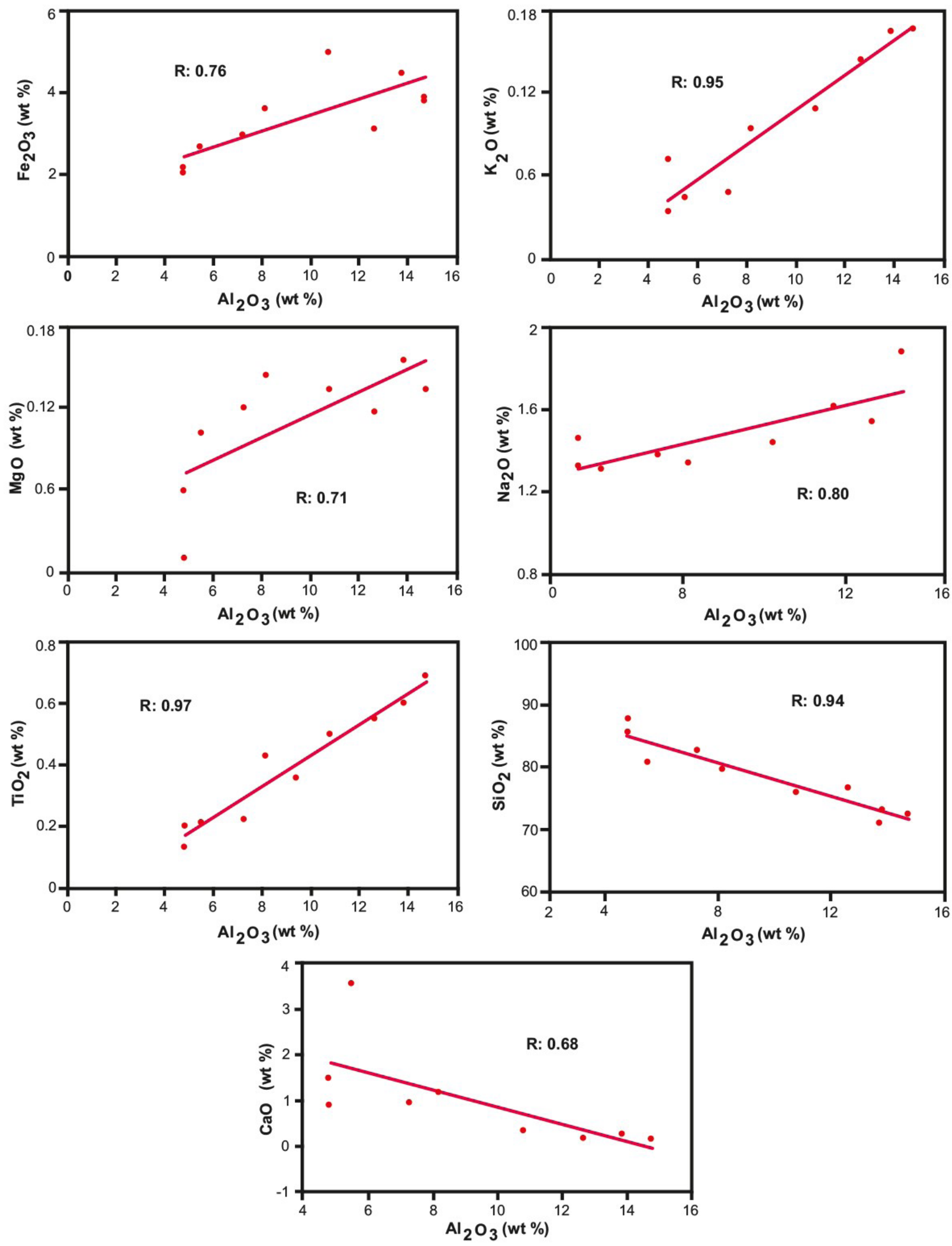

Figure 12 Investigating the changes of major oxides versus $\mathrm{Al}_{2} \mathrm{O}_{3}$ in the Qadir Member sandstones. 
useful information about the provenance of sedimentary rocks (Von Eynatten et al., 2003), because of the mafic and felsic source rocks vary significantly in different proportions (Salehi et al., 2014). The trace elements (Co, Nb, Ni, Rb, Th, V, and $\mathrm{Y}$ ) in sandstones depict a positive relationship with the amount of $\mathrm{Al}_{2} \mathrm{O}_{3}$, presented in Table 5. Increasing the amount of these elements with increasing of $\mathrm{Al}_{2} \mathrm{O}_{3}$ shows the presence of clay minerals (Akarish and El-Gohary, 2008; Zaid, 2015).

Basu et al (1975) used different types of undulatory extinction and the number of quartz crystals to interpret the provenance of sandstones. According to this diagram, 2 to 3 crystals or more than 3 were located in large vertices, while non-undulatory and undulatory quartz were located in small vertices. Based on the sandstone modal analysis (Table 2 and 3) on this diagram, the source rock of Qadir Member was largely from the middle to low-rank metamorphic and slightly plutonic rocks (Figure 13). Also, based on the Schieber (1992) diagram, due to the placement of $\mathrm{Al}_{2} \mathrm{O}_{3}$ against $\mathrm{TiO}_{2}$ for separating basic, intermediate and felsic source rocks, the setting for Qadir Member sandstones was plotted to a great extent around granodiorite and a lesser extent around granite and mafic rocks (Figure 14a). The Roser and Korsch (1988) function diagram is also used to differentiate sediments in four ranges of mafic igneous, intermediate igneous, felsic igneous, and quartz sedimentary provenance (Figure 14b), which represent sedimentary provenance. On the other hand, based on the diagram of the $\mathrm{TiO}_{2}$ versus $\mathrm{Al}_{2} \mathrm{O}_{3}$, the range of sandstones on this diagram shows granite to granodiorite source rocks. Based on the diagram of $\mathrm{Zr}$ versus $\mathrm{TiO}_{2}$, the sandstones have been often plotted around the felsic igneous to intermediate igneous rocks (Figure 14c). It should be noted that the zircon is conducted by heavy minerals plotted in an inter-

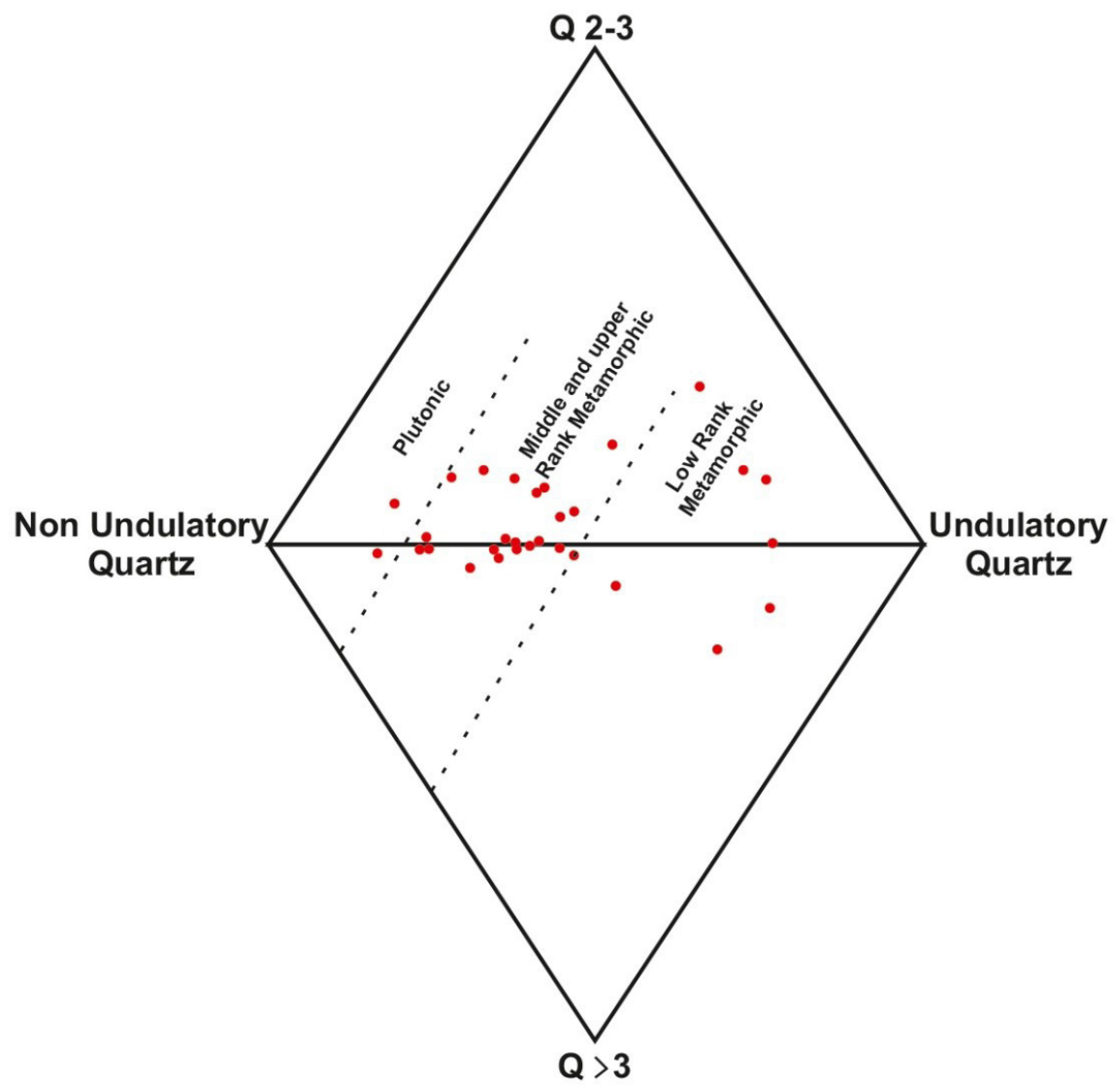

Figure 13 The Qadir Member sandstones source rock based on Basu et al., 1975 diagram. 
mediate igneous source rock (Paikaray et al., 2008) and the mineral's host is mainly zircon (Zaid, 2015). In diagram of $\mathrm{Al}_{2} \mathrm{O}_{3}-\left(\mathrm{CaO}+\mathrm{Na}_{2} \mathrm{O}+\mathrm{K}_{2} \mathrm{O}\right)$ - $(\mathrm{FeO}+\mathrm{MgO})$, according to Hayashi et al., 1997, placement of samples around illite and smectite represents the nature of intermediate felsic source rock (Figure 14d). Thus, based on these diagrams, the sedimentary and intermediate igneous source rock can be proposed for the Qadir Member from the Nayband Formation.

\subsection{DEPOSITIONAL AND TECTONIC SETTING}

To determine the depositional environments of sediments, the $\mathrm{P}_{2} \mathrm{O}_{5}\left(\mathrm{wt}^{\mathrm{O}} \%\right)$ and $\mathrm{Al}_{2} \mathrm{O}_{3}(\mathrm{wt} \%)$ bivariate diagram are used (Dhannoun and Al-Dlemi, 2013). Figure 15a indicates that most sandstone samples of the Qadir Member were plotted in shallow marine environments which further indicate lower values of phosphorous due to lower biologic activity during the latest Triassic (Norian to Rhaetian). Also, Similar results were drawn from $\mathrm{V}$ (ppm)-Al2O3 (wt \%) bivariate plot (Dhannoun and Al-Dlemi, 2013) as shallow marine-fluvial depositional settings of the Qadir Member (Figure 15b). Then, Qadir Member deposits have been originated in shallow marine environments. The deposition of Qadir Member occurred in restricted shallow marine in oxygenated conditions during late Triassic time (Tables
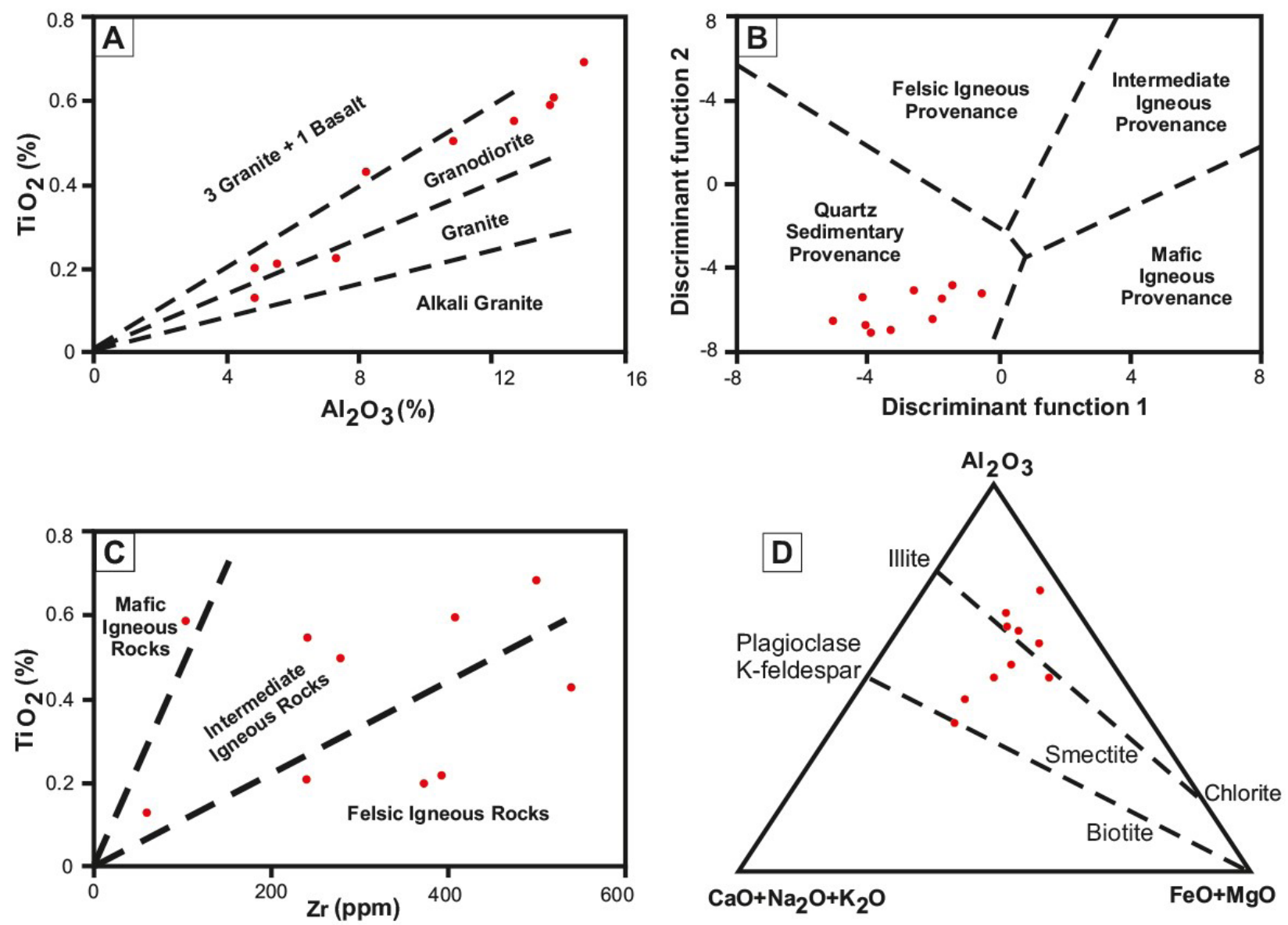

Figure 14 Investigating the Qadir Member sandstones source rock based on different diagrams. A) The ratio of $\mathrm{Al}_{2} \mathrm{O}_{3}$ major oxides compared with $\mathrm{TiO}_{2}$ (Schieber, 1992), B) Discriminant plot for sandstones using major elements oxides (Roser and Korsch, 1998). Discriminant function $1:\left(-1.773 \times \mathrm{TiO}_{2} \%\right)+\left(0.607 \times \mathrm{Al}_{2} \mathrm{O}_{3} \%\right)+\left(0.76 \times \mathrm{Fe}_{2} \mathrm{O}_{3}(\mathrm{~T}) \%\right)+\left(-1.5 \times \mathrm{MgO}^{2}\right)+\left(0.616 \times \mathrm{CaO}^{2}\right)+\left(0.509 \times \mathrm{Na}_{2} \mathrm{O} \%\right)+$ $\left(-1.22 \times \mathrm{K}_{2} \mathrm{O} \%\right)+(-9.09)$. Discriminant function $2:\left(0.445 \times \mathrm{TiO}_{2} \%\right)+\left(0.07 \times \mathrm{Al}_{2} \mathrm{O}_{3} \%\right)+\left(-0.25 \times \mathrm{Fe}_{2} \mathrm{O}_{3}(\mathrm{~T}) \%\right)+\left(-1.142 \times \mathrm{MgO}^{2}\right)+\left(0.432 \times \mathrm{Na}_{2} \mathrm{O} \%\right)$ $\left.+\left(1.426 \times \mathrm{K}_{2} \mathrm{O} \%\right)+(-6.861) . \mathrm{C}\right) \mathrm{TiO}_{2}$ (wt.\%) versus $\mathrm{Zr}(\mathrm{ppm})$ bivariate diagram (Paikaray et al., 2008), D) Drawing the data in the ternary diagrams $\mathrm{Al}_{2} \mathrm{O}_{3}-\left(\mathrm{CaO}+\mathrm{Na}_{2} \mathrm{O}+\mathrm{K}_{2} \mathrm{O}\right)-(\mathrm{FeO}+\mathrm{MgO})($ Hayashi et al., 1997). 
4 and 5). Also, the composition of sandstones is controlled by the diagenetic processes, transport distance, and type of source rock (Akarish and El-Gohary, 2008). In fact, the sandstones document significant data about the orogeny cycles and that is why determination of the origin and destination provides a better understanding of the tectonic status and their development (Shi et al., 2016). The tectonic setting of Qadir Member is interpreted using the modal analysis and geochemical data (Table 2 and 3). Dickinson and Suczek (1979) and Dickenson et al., 1983 related the compositions of terrigenous sandstones to various types of major provenance. Conducting the modal analysis of sandstones (Table 2 and 3) in the ternary diagram Qm-F-Lt (Dickisnon and Suczek, 1979), the provenance of sandstones was quartzose recycled and a few samples were plotted on the transitional recycled (Figure 15c). The frequency and existence of monocrystalline quartz in comparison with polycrystalline in the samples could show high energy depositional setting, long transport, and/or sedimentary recycling of these particles (Tucker, 2009).

On the other hand, Bhatia (1983) and Roser and Korsch (1986) divided the tectonic setting of the sedimentary basins into four types of continental island arcs, oceanic island arcs, active continental margin, and passive continental margin based on the geochemical criteria of major elements in sandstones. Plotting the data of the Qadir Member sandstones on the Bhatia (1983) diagram shows that the majority of the samples are plotted on the active continental margin and a few samples are plotted on the passive continental margin (Figure 15d). In addition, based on the Roser and Korsch (1986) diagram (Figure 15e), active continental margin can be interpreted for theses sandstones. These results can be due to the tectonic activities and occurrence of the Early Cimmerian orogeny in the boundary of middle and Late Triassic (the Boundary between Shotori Formation and Nayband Formation) and also limited volcanic activity in the arc and the very broad extensional retro-arc zone, concurrent with the orogeny phase of Early Cimmerian in the
Central-East Iranian Microcontinent (CEIM; the occurrence of Early Cimmerian; for example, Stöcklin, 1974; Stampfli and Borel, 2002; Fürsich et al., 2005; Fürsich et al., 2009; Wilmsen et al., 2009a; Zamaniyan et al., 2019).

\subsection{SOURCE AREA WEATHERING}

Mineralogy and chemical composition of terrigenous sediments is controlled with various factors such as the composition of a source region and can be changed by weathering in the source region and tectonic setting (Bauluz et al., 2000; Garzanti and Resentini, 2016). Alteration of igneous rocks during weathering results in depletion of alkali and alkaline earth elements and preferential enrichment of $\mathrm{Al}_{2} \mathrm{O}_{3}$ in sediments (Garcia et al., 2004; Osae et al., 2006). The history of weathering of the rocks is often calculated by the ratio of movable oxides such as $\mathrm{CaO}, \mathrm{K}_{2} \mathrm{O}$ and $\mathrm{Na}_{2} \mathrm{O}$ to unmovable ones (Bayet-Goll and Hosseini Barzi, 2011). To identify the rate of chemical weathering, Chemical Index of Alteration (CIA) was used (Nesbitt and Young, 1982) and calculated by the following formula:

$$
C L A=\left[\mathrm{Al}_{2} \mathrm{O}_{3} /\left(\mathrm{Al}_{2} \mathrm{O}_{3}+\mathrm{CaO}+\mathrm{Na}_{2} \mathrm{O}+\mathrm{K}_{2} \mathrm{O}\right)\right] * 100
$$

The amount of CIA was low, medium and high and was related to the chemical alteration from low to high; ranging from 50 to 100 . Low CIA suggests low amount of alteration and dry and cold climate conditions, while high CIA suggests warm and humid climate conditions (Nesbitt and Young, 1982). Considering the given calculations, the rate of CIA from Qadir Member ranges from 50.97 to 80.03 with an average of $71.26 \%$ (Table 4 ), according to which, medium to rather a high chemical weathering of rocks is shows in the source region and during transport to the depositional site. This rate of weathering can be due to humid weather which intensifies the weathering of the rocks (Khanehbad et al., 2012a, 2012b). Based on the Suttner and Dutta (1986) diagram, the amount of $\mathrm{SiO}_{2}$ against the total percentage of $\mathrm{Al}_{2} \mathrm{O}_{3}+\mathrm{K}_{2} \mathrm{O}+\mathrm{Na}_{2} \mathrm{O}$ was used as another weather 
performance to identify the chemical maturity of sandstones. Plotting our data on this diagram, the weather conditions are specified to be semi-arid to semi-humid for the given samples (Figure 16a) and this climatic situation is also supported by palynoflora studies by Sajjadi et al. (2015) in southeastern Tabas implying a moist warm climate. However, based on study by Cirilli et al. (2005) on the Nay- band Formation, a change from humid to drier and warmer (tropical to subtropical) conditions is recorded. The CIA values plotted on the triangle diagram of $\mathrm{Al}_{2} \mathrm{O}_{3}-\mathrm{CaO}+\mathrm{Na}_{2} \mathrm{O}-\mathrm{K}_{2} \mathrm{O}$ or $\mathrm{A}-\mathrm{CN}-\mathrm{K}$ (Paikaray et al., 2008) suggest the change in the sample's compositions along with the change of chemical weathering and composition of provenance region. According to this diagram, the
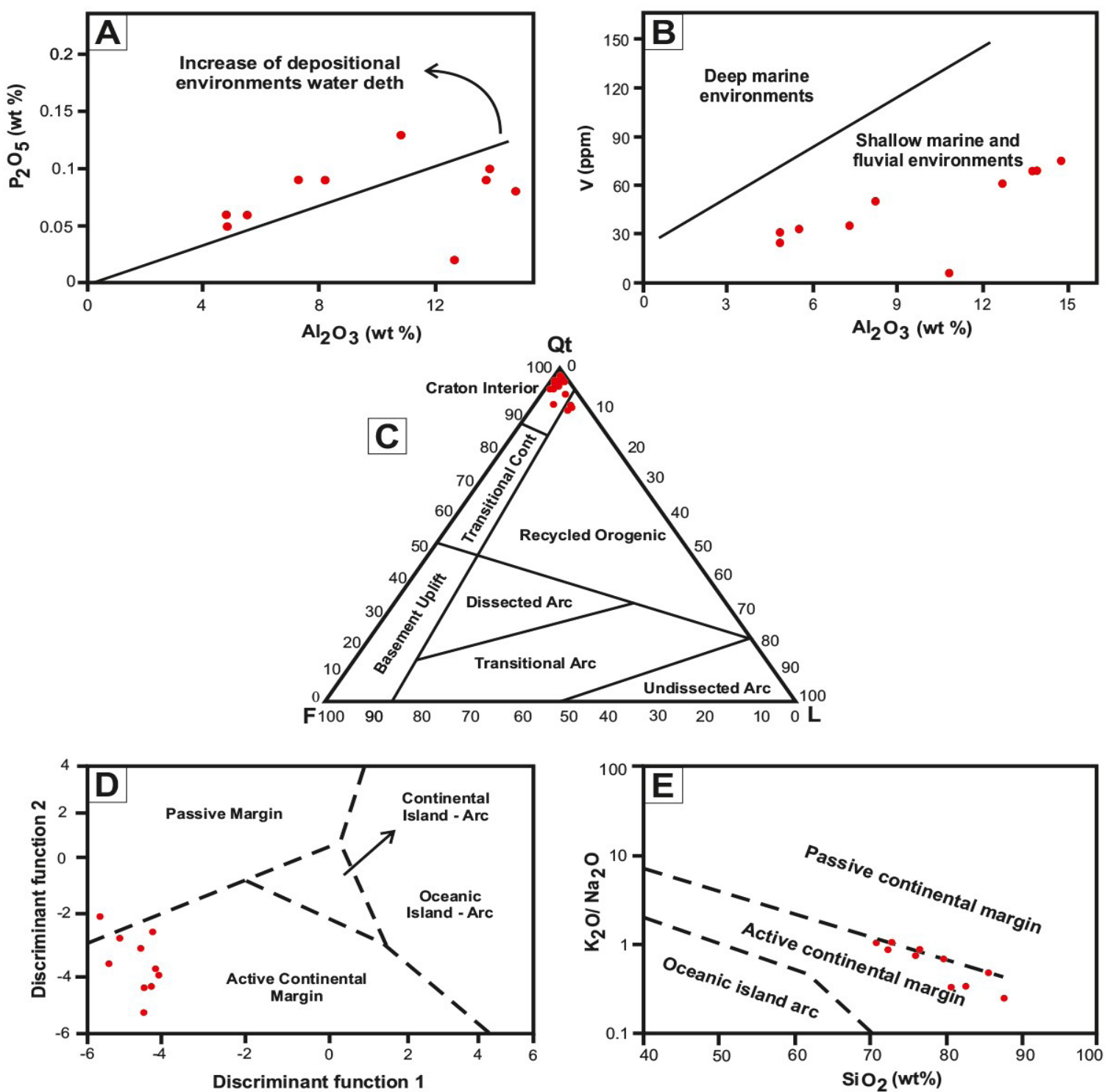

Figure 15 A) $\mathrm{P}_{2} \mathrm{O}_{5}-\mathrm{Al}_{2} \mathrm{O}_{3}$ (Dhannoun and Al-Dlemi, 2013) showing shallow marine depositional settings of the Qadir Member, $\mathrm{B}$ ) $\mathrm{V}$ - $\mathrm{Al}_{2} \mathrm{O}_{3}$ plots (Dhannoun and Al-Dlemi, 2013) refer shallow marine and fluvial environments for Qadir Member, C) The tectonic setting of Qadir Member sandstones based on the Modal analysis (Dickinson and Suczek, 1979), D) Discrimination function analysis classification plot using major elements oxides (Bhatia, 1983). Discriminant function 1: $\left(-0.0447 \times \mathrm{SiO}_{2} \%\right)+\left(-0.972 \times \mathrm{TiO}_{2} \%\right)+\left(0.008 \times \mathrm{Al}_{2} \mathrm{O}_{3} \%\right)+\left(-0.267 \times \mathrm{Fe}_{2} \mathrm{O}_{3} \%\right)$ $+(0.208 \times \mathrm{FeO} \%)+(-3.082 \times \mathrm{MnO} \%)+(0.140 \times \mathrm{MgO} \%)+(0.195 \times \mathrm{CaO} \%)+\left(0.719 \times \mathrm{Na}_{2} \mathrm{O} \%\right)+\left(-0.032 \times \mathrm{K}_{2} \mathrm{O} \%\right)+\left(7.510 \times \mathrm{P}_{2} \mathrm{O}_{5} \%\right)$. Discriminant function $2:\left(-0.421 \times \mathrm{SiO}_{2} \%\right)+\left(1.988 \times \mathrm{TiO}_{2} \%\right)+\left(-0.526 \times \mathrm{Al}_{2} \mathrm{O}_{3} \%\right)+\left(-0.551 \times \mathrm{Fe}_{2} \mathrm{O}_{3} \%\right)+(-1.610 \times \mathrm{FeO} \%)+(2.720 \times \mathrm{MnO} \%)+(0.881 \times \mathrm{MgO})+(-0.907 \times \mathrm{CaO} \%)+$ $\left(-0.117 \times \mathrm{Na}_{2} \mathrm{O} \%\right)+\left(-1.840 \times \mathrm{K}_{2} \mathrm{O} \%\right)+\left(7.244 \times \mathrm{P}_{2} \mathrm{O}_{5} \%\right)$. E) Tectonic setting diagram for Sandsones of Qadir Member (Roser and Korsch, 1998). 
first stages of weathering has a parallel procedure with A-GN side (Bayet-Goll and Hosseini Barzi, 2011) since throughout the first stages of weathering, sodium, and potassium ions are removed by alteration of feldspars (Plagioclase), and as the K-feldspars weathering proceeds, potassium ions reduce and weathering procedure changes toward $\mathrm{Al}_{2} \mathrm{O}_{3}$ composition (Paikaray et al., 2008). That is, in advanced weathering, an obvious drop in the value of $\mathrm{K}_{2} \mathrm{O}$ emerges with the composition movement of these elements toward the vertex A (Nesbitt and Young, 1984). Plotting these data on the diagram, the sandstone samples are often plotted in the range of smectite and illite and less in the contour $\mathrm{Al}_{2} \mathrm{O}_{3}-\mathrm{Pl}$ (Figure 16c). This depicts a rather severe weathering for the Qadir Member sandstones while not drawing the samples in the contour $\mathrm{Al}_{2} \mathrm{O}_{3}-\mathrm{K}_{2} \mathrm{O}$ indicates that no severe weathering has happened in the source area. Given that the samples have been plotted in the range of smectite and illite and to a lesser extent in contour $\mathrm{Al}_{2} \mathrm{O}_{3}-\mathrm{Pl}$, it can be concluded that these results show rather unstable condition of tectonic in the semi-arid to semi-humid weather conditions which have affected sediments by the active continental margin (Zamaniyan et al., 2019; Etesampour et al., 2019).

The relationship between weathering and source rock compositions can be assessed by the relationship between Index of Compositional Variability (ICV) and Chemical Index of Alteration (CIA; Cox et al., 1995; Potter et al., 2005). ICV could be employed to identify and separate types of source rock based on major elements of geochemistry. The relationship is as follows:

$I C V=\left(\mathrm{Fe}_{2} \mathrm{O}_{3}+\mathrm{K}_{2} \mathrm{O}+\mathrm{Na}_{2} \mathrm{O}+\mathrm{CaO}+\mathrm{MgO}+\mathrm{TiO}_{2}\right) / \mathrm{Al}_{2} \mathrm{O}_{3}$

The ICV value suggests that the value of this index is inversely related to the value of weathering, in other words, when the value of this index increases, the value of weathering reduces and the high value of ICV $(>1)$ suggests that the immature source rocks are full of silicate minerals with lack of any clay minerals. On the other hand, the lesser ICV $(<1)$ value, the more mature will be the source rock (Cox et al., 1995). Rock-forming minerals such as plagioclase, K-feldspars, amphiboles, and pyroxenes show ICV values $>0.84$, whereas typical alteration products such as kaolinite, illite, and muscovite show values $<0.84$ (Cox et al., 1995; Cullers, 2000). The average ICV value for the Qadir Member sandstones was about 1.01 (Table 4) which represents sub maturity to immaturity of these sandstones to form clay minerals, indicating that the minerals have been less affected by the alteration. Besides, by plotting the ICV diagram against the CIA based on the method of Lee (2002), the Qadir Member sandstones from Nayband Formation show a source of intermediate igneous rocks (Figure16b).

\subsection{PALEO-OXYGENATION GONDITION}

Geochemical data have been used by various authors to understand the paleo-oxygenation condition of ancient sediments. The $\mathrm{V} / \mathrm{Cr}$ ratio has been used as an index of paleo-oxidation in many studies (Dill et al., 1988; Khanehbad et al., 2012 b). Ratios $>2$ indicate anoxic conditions, while values $<2$ suggest more oxidizing conditions (Jones and Manning, 1994). The average $\mathrm{V} / \mathrm{Cr}$ ratio for sandstones of Qadir Member is 0.81 (Table 5), indicating that these sandstones were deposited in oxic conditions. Also, the $\mathrm{Ni} / \mathrm{Co}$ ratio $<5$ indicates oxidizing environments, whereas ratio $>5$ suggests suboxic and anoxic environments (Jones and Manning, 1994). The average Ni/Co ratio for sandstones of this section is 4.93 , which shows that these sandstones were deposited in oxic environments. These ratios were determined for samples in Table 5. On the other hand, new studies show that the siliciclastic deposits of the Nayband Formation (Qadir Member) have settled in deltaic and coastal environments, where they are affected by oxidant conditions (For examples: Fürsich et al., 2005; Bayet-Goll and Carvalho, 2017; Zamaniyan et al., 2019). 


\subsection{PALEOGEOGRAPHY}

Iranian plate is made of Central-East Iranian Microcontinent (CEIM), northwestern Mountains and Alborz, separated from the northeastern margin of Gondwana during the Early Permian (Stampfli and Borel, 2002). It led to the closure of Paleotethys by moving northward during the Triassic and collided with Laurasia and Turan plates following the Late Triassic Neotethyan subduction (Berberian and King, 1981; Davoudzadeh and Schmit, 1983; Stampfli and Borel, 2002; Zanchi et al., 2009; Wilmsen et al., 2010; Cifelli et al., 2013; Sheikholeslami, 2016). However, the precise age of collision is still under discussion (Şengör et al., 1988; Alavi et al., 1997; Seyed-Emami, 2003;
Golonka, 2004). The sedimentary cycle of the Late Triassic to the Middle Jurassic has happened between two tectonic events: Early Cimmerian and Middle Cimmerian (Fürsich et al., 2009). During the Norian time (Nayband Formation as the first Formation from the Shemshak group of Central Iran), the strongly depressed block of Tabas, in the coastal and marine conditions, the sand-silty sediments were formed with the thickness of $1000 \mathrm{~m}$ and in the Rhaetian time, the Qadir Member from the Nayband Formation took the form of transitional-marine environments (Shahrabi, 1999). During the Late Triassic time (Norian-Rhaetian), Neotethys subduction started at the southern margin of Iran plate and this event reduced compression of the Iran Plate with subsequent formation

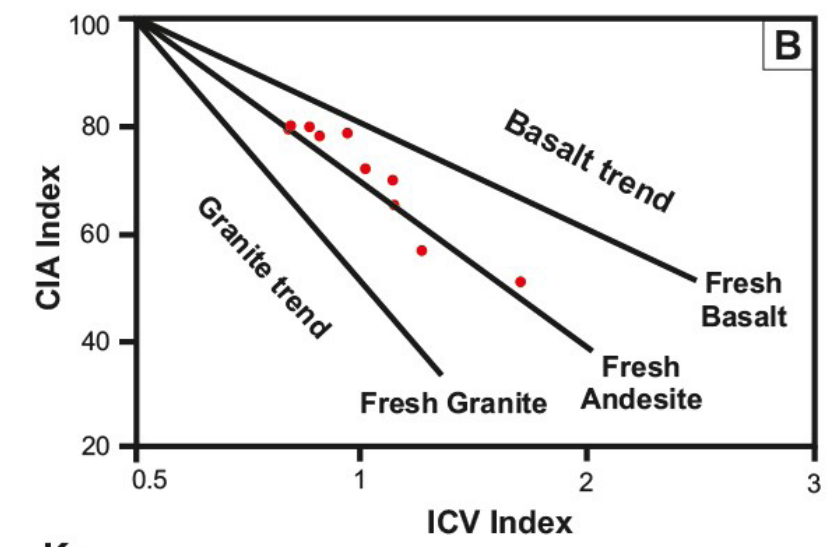

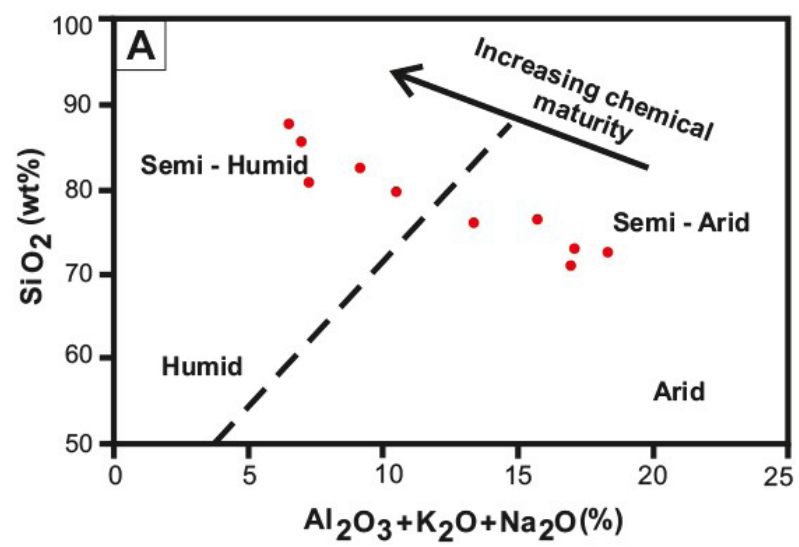

Figure 16 Investigation and procedure of Qadir Member sandstones weathering. A) The Suttner and Dutta (1986) dual diagram suggest semi-arid to semi-humid weather, B) ICV dual diagram against CIA (Cox et al., 1995) suggest the intermediate igneous rock source, C) the A-CN-K triangular diagram (Paikaray et al., 2008) (Ka: Kaolinite, Sm: Smectite, IL: Illite PI: Plagioclase, Gr: Granite, K-F: K-Feldspar). 

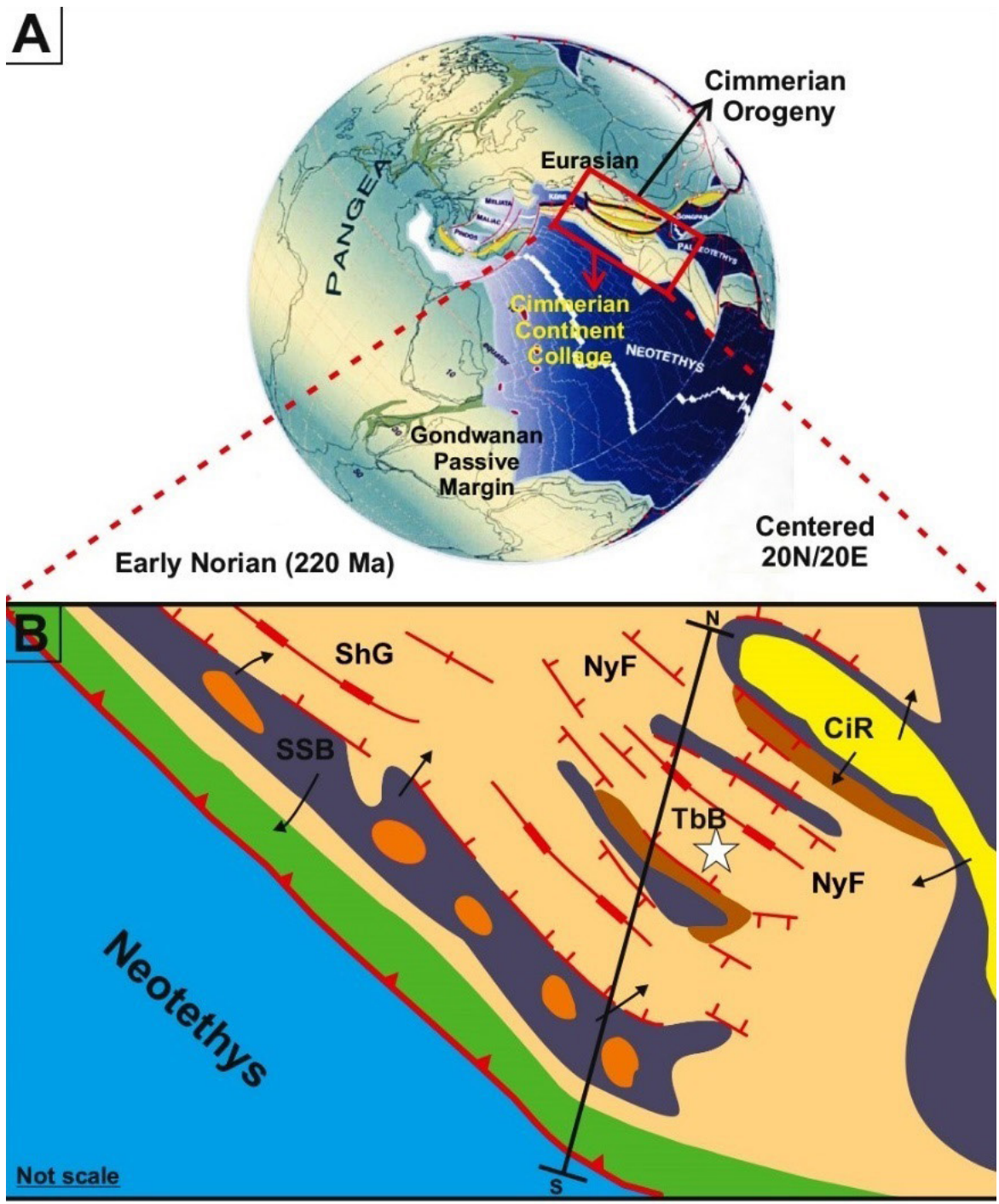

Legend
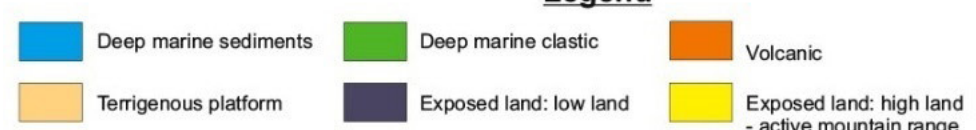
Exposed land: high land
- active mountain range

NyF: Nayband SSB: Sanandaj-Sirjan Block TbB: Tabas Block CiR: Cimmerian Range ShG: Shemshak Group

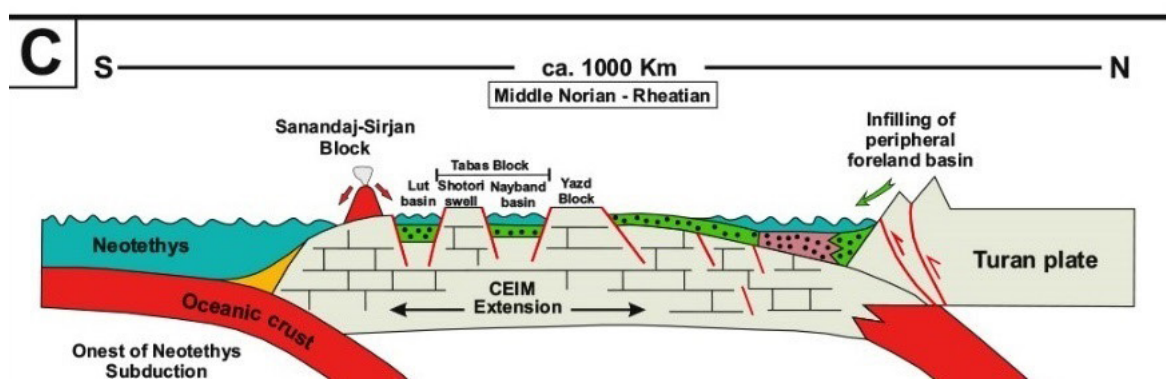

Figure 17 A) Geodynamic model of late Triassic for the Cimmerian Orogeny in Iran, (modified after Stampfli and Borel, 2002), B) palaeogeographic sketches of the Late Triassic (Middle Norian-Rheatian) for the Early Cimmerian Orogeny on the Iran Plate (modified after Barrier and Vrielynck, 2008) and the study area is indicated by a white asterisk on b, C) Geodynamic model for the Cimmerian Orogeny in Iran and the middle-late Triassic evolution of the Iran Plate. (A-C) Different time slices representing important phases of the model (not to scale; CEIM, Central-East Iranian Microcontinent) (modified after Wilmsen et al., 2009b). 
(Nayband Basin) of extensional basins and transgression of the sea onto the Iran Plate (Wilmsen et al., 2009b; Fürsich et al., 2005). In that period, Iran was located in Latitude of $25^{\circ}-30^{\circ}$ North (Figures 17a and 17b: geodynamic model (Stampfli and Borel, 2002) and palaeogeographic sketches (modified after Barrier and Vrielynck, 2008)). Accordingly, our interpretation of semi-humid to semi-arid climate condition discussed above is supported and other studies (for example: Cirilli et al., 2005; Sajjadi et al., 2015; Zamaniyan et al., 2019). On the other hand, the active continental margin conditions, based on the Bhatia (1983) and Roser and Korsch (1998) diagrams, could imply Neotethys subduction under Iran's plate for sandstones of Qadir Member, while Iran's collision with Eurasia and Turan at the end of Triassic period could be also suggested (Figure17c: geodynamic model; Wilmsen et al., 2009b). Also, the shallow angle of Neotethys subduction beneath SW Iran (Ghasemi and Talbot, 2006) caused the limited volcanic activity in the arc and the very broad extensional retro-arc zone (Salehi et al., 2018; Zamaniyan et al., 2019, Etesampour et al., 2019).

\section{Conclusion}

The Qadir Member of the Nayband Formation (Late Triassic) with a thickness of $450 \mathrm{~m}$ is mainly made of siliciclastic sediments along with the coal layers and thin-layers of limestone, and divided into units 1 and 2. Facies and field analysis in the studied section resulted in the identification of four medium to coarse-grained facies including $\mathrm{Sr}, \mathrm{Sh}, \mathrm{Sp}$ and St, three fine-grained lithofacies of Fl, Fm, $(\mathrm{Sr}) \mathrm{Fl} /(\mathrm{Fl}) \mathrm{Sr}$ and one coal $(\mathrm{C})$ facies, together with carbonate facies in the size of calcarenite and calcirudite. Analysis of facies identified in the Qadir Member led to the identification of coastal plain, delta plain, proximal delta front, distal delta front, Prodelta and shallow parts of the open marine. The presence of fining upward cycles and sedimentary structures such as herringbone cross-bedding, types of ripples, trough cross-bedding, and different trace fossils, along with coal and carbonate facies, all suggest deposition of Qadir Member sediments in the tide-dominated delta and shallow parts of the open marine. Also, geochemical data of siliciclastic deposits show that they are sublitharenite and slightly subarkose with the medium-well sorting. The modal and geochemical analysis depicts the recycling provenance and tectonic setting of the active continental margin. This could be related to the tectonic activities of the Late Cimmerian event (the Middle and Late Triassic), Neotethys subduction and collision of Iran's plate with Turan that could be related to the period of Late Triassic time which was concurrent with the orogeny phase and volcanic activity in the Central-East Iranian Microcontinent (CEIM). Also, according to the geochemical data, the combination of source rock is sedimentary and intermediate igneous rocks for the studied section. The coefficient of chemical weathering is rather medium to high, which suggests these sediments are affected by the semi-arid to semi-humid climatic conditions. Also, based on paleo-oxygenation these sandstones were deposited in oxic environments.

\section{Acknowledgements}

This research represents part of the senior author's M.S. thesis and was supported by the Department of Geology, Ferdowsi University of Mashhad (research code: 3/38412), Iran. We thank Tabas Parvadeh Coal Company (TPCCO) for providing facilities during field studies. Thanks for the valuable suggestions from Dr. Ali Bahrami, editor of Boletín de la Sociedad Geológica Mexicana. We would like to acknowledge the two anonymous reviewers for their review and comments that improved our manuscript significantly.

\section{References}

Aboumaria, K., Zaghloul, M.N., Battaglia, M., Loiacono, F., Puglisi, D., Aberkan, M.H., 2009, Sedimentary processes and provenance of Quaternary marine formations from the Tangier Peninsula (Northern Rif, Morocco): 
Journal of African Earth Sciences, 55(12), 10-35. https://doi.org/10.1016/j. jafrearsci.2008.12.004

Aghanabati, A., 2006, Geology of Iran: Geological survey of Iran, 586p. (In Persian).

Akarish, A.I., El-Gohary, A.M., 2008, Petrography and geochemistry of lower Paleozoic sandstones, East Sinai, Egypt: Implications for provenance and tectonic setting: Journal of African Earth Sciences, 52(1), 43-54. https:// doi.org/10.1016/j.jafrearsci.2008.04.002

Alavi, M., Vaziri, H., Seyed-Emami, K., Lasemi, Y., 1997, The Triassic and associated rocks of the Nakhlak and Aghdarband areas in central and northeastern Iran as remnants of the southern Turanian active continental margin: Geological Society of America Bulletin, 109(12), 1563-1575. https://doi. org/10.1130/0016-7606 (1997)109<1563: ttaaro $>2.3 . \mathrm{co} ; 2$

Barrier, E., Vrielynck, B., 2008, Palaeotectonic maps of the Middle East - tectono sedimentary palinsspastic maps from the Late Norian to Pliocene: Paris Commission for the Geological Map of the World; CGMW/ CCGM).

Basu, A., Young, S.W., Suttner, L.J., James, W.C., Mack, G.H., 1975, Re-evaluation of the use of undulatory extinction and polycrystallinity in detrital quartz for provenance interpretation: Journal of Sedimentary Petrology, 45(4), 873882. https://doi.org/10.1306/212f6e6f2b24-11d7-8648000102c1865d

Bauluz, B., Mayayo, M.J., Fernandez-Nieto, C., Lopez, J.M.G., 2000, Geochemistry of Precambrian and Paleozoic siliciclastic rocks from the Iberian Range (NE Spain): implications for source-area weathering, sorting, provenance, and tectonic setting: Chemical Geology, 168(1), 135-150. https:// doi.org/10.1016/s0009-2541 (00)00192-3

Bayet-Goll, A., Carvalho, C.N.D., 2017, Differentiation of delta and open marine deposits based on an integrated ichnological and sedimentological analysis of the Late Triassic Nayband Formation, Tabas Block,
Central Iran: Journal of Iberian Geology, 43(3), 413-437. https://doi.org/10.1007/ s41513-017-0031-5

Bayet-Goll, A., Hosseini Barzi. M., 2011, Geochemistry of major elements of siliciclastic deposits from Shirgesht Formation, in Kalmard block, Central Iran, implications for provenance, tectonic setting, and weathering intensity: Journal of Scientific Quarterly Geosciences, 20(79), 101112. (In Persian). https://doi.org/10.22071/ GSJ.2011.55051

Berberian, M., King, G.C.P., 1981, Towards a paleogeography and tectonic evolution of Iran: Canadian Journal of Earth Sciences, 18(2), 210-265. https://doi.org/10.1139/ e81-162

Bhatia, M.R., 1983, Plate tectonics and geochemical composition of sandstones: Journal of Geology, 91(6), 611-627. https:// doi.org/10.1086/628815

Bhatia, M.R., Crook, K.A., 1986, Trace element characteristics of graywackes and tectonic setting discrimination of sedimentary basins: Contributions to Mineralogy and Petrology, 92(2), 181-193. https://doi.org/10.1007/ bf00375292

Bos, I.J., 2010, Architecture and facies distribution of organic-clastic lake fills in the fluvio-deltaic Rhine-Meuse system, The Netherlands: Journal of Sedimentary Research, 80, 339-356. https://doi. org/10.2110/jsr.2010.035

Bronifman, P., Zaninetti, L., Bozorgnia, F., Dashti, G. R., Moshtaghian, A., 1971, Lithostratigraphy and foraminifera of the Triassic Naiband Formation, Iran: Revista de Micropaleontologia France, 14(0005), 7-16.

Cadjenovic, D., Kilibarda, Z., Radulovic, N., 2008, Triassic to Late Jurassic evolution of the Adriatic carbonate platform and Budva Basin, Southern Montenegra: Sedimentary Geology, 204, 1-17. https:// doi.org/10.1016/j.sedgeo.2007.12.005

Carlos, A.U., Ronald,J. S., 2008, A highstand shelfmargin delta system from the Eocene of West 
Spitsbergen, Norway: Sedimentary Geology, 203, 229-245. https://doi.org/10.1016/j. sedgeo.2007.12.003

Catuneanu, O., 2003, Sequence Stratigraphy of Clastic Systems: Geological Association of Canada, Short Course Notes, 16, 248p.

Cifelli, F., Mattei, M., Rashid, H., Ghalamghash,J., 2013, Right-lateral transpressional tectonics along the boundary between Lut and Tabas blocks (Central Iran): Geophysical Journal International, 193, 1153-1165. https:// doi. org/10.1093/gji/ggt070

Cirilli, S., Buratti, N., Senowbari-Daryan, B., Fürsich, F.T., 2005, Stratigraphy and palynology of the Upper Triassic Nayband formation of east-central Iran: Rivista Italiana di Paleontologia e Stratigrafia, 111, 259-270. https://doi.org/10.13130/2039-4942/6312

Coffey, B.P., Read, J.F., 2004, Mixed carbonate - siliciclastic sequence stratigraphy of a Paleogene transition zone continental shelf, Southeastern USA: Sedimentary Geology, 166, 21-57. https://doi.org/10.1016/j. sedgeo.2003.11.018

Cotter, E., Driese, S.G., 1998, Incised valley fills and other evidence of sea level fluctuations affecting deposition of the Catskill formation (Upper Devonian), Appalachian Forland Basin, Pennsylvania: Journal of Sedimentary Petrology, 62, 1130-1146. https://doi.org/10.1306/ d42687a7-2b26-11d7-8648000102c1865d

Cox, R., Lowe, D.R., Cullers, R.L., 1995, The influence of sediment recycling and basement composition on evolution of mudrock chemistry in the southwestern United States: Geochimica et Cosmochimica Acta, 59(14), 2919-2940. https://doi.org/10.1016/00167037 (95)00185-9

Critelli, S., 1993, Sandstone detrital modes in the Paleogene Liguride Complex, accretionary wedge of the southern Apennines (Italy): Journal of Sedimentary Research, 63(3), 464-476. https://doi.org/10.1306/ d4267b27-2b26-1 1d7-8648000102c1865d

Cullers, R.L., 2000, The geochemistry of shales, siltstones and sandstones of PennsylvanianPermian age, Colorado, USA: implications for provenance and metamorphic studies: Lithos, 51(3), 181-203. https://doi. org/10.1016/s0024-4937 (99)00063-8

Dabard, M.P., 1990, Lower Brioverian Formations (Upper Proterozoic) of the Armorican Massif (France): geodynamic evolution of source areas revealed by sandstone petrography and geochemistry: Sedimentary Geology, 69(1-2), 45-58. https://doi.org/10.1016/0037-0738 (90)90100-8

Dalrymple, R.W., Zaitline, B.A., Boyd, R., 1992, Estuarine facies models: Conceptual basis and stratigraphic implications: Journal of Sedimentary Petrology, 62, 1130-1146. https://doi.org/10.1306/ d4267f55-2b26-1 1d7-8648000102c1865d

Das, B.K., Al-Mikhlafi, A.S., Kaur, P., 2006, Geochemistry of Mansar Lake sediments, Jammu, India: Implication for sourcearea weathering, provenance, and tectonic setting: Journal of Asian Earth Sciences, 26(6), 649-668. https://doi.org/10.1016/j. jseaes.2005.01.005

Davis, R.A., 2012, Tidal signatures and their preservation potential in stratigraphic sequences, in Davis, R.A. and Dalrymple, R.W. (Eds.), Principles of Tidal Sedimentology, Springer, 35-55. https://doi. org/10.1007/978-94-007-0123-6_3

Davoudzadeh, M., Schmit, K., 1983, A review of Mesozoic paleogeography and tectonic evolution of Iran, Tehran: Geological Survey of Iran, 51, 415-435.

Dhannoun, H.Y., Al-Dlemi, A.M.S., 2013, The relation between $\mathrm{Li}, \mathrm{V}, \mathrm{P}_{2} \mathrm{O}_{5}$, and $\mathrm{Al}_{2} \mathrm{O}_{3}$ contents in marls and mudstones as indicators of environment of deposition: Arabian Journal of Geosciences, 6, 817-823. https:// doi.org/10.1007/s12517-011-0399-z

Dickinson, W.R., 1985, Interpreting Provenance Relations from Detrital Modes of Sandstones, in Zuffa G.G. (ed.), Provenance of Arenites. Springer, Dordrecht, 333-363. https://doi. org/10.1007/978-94-017-2809-6_15 
Dickinson, W.R., Beard, L.S., Brakenridge, G.R., Erjavec, J.L., Ferguson, R.C., Inman, K.F., Lindberg, F.A., Ryberg, P.T., 1983, Provenance of North American Phanerozoic sandstones in relation to tectonic setting: Geological Society of America Bulletin, 94(2), 222-235. https://doi.org/10.1130/00167606 (1983)94\%3C222:ponaps\%3E2.0.co;2

Dickinson, W.R., Suczek, G.A., 1979, Plate tectonics and sandstone compositions: American Association of Petroleum Geologists Bulletin, 12, 2164-2182. https:// doi.org/10.1306/2f9188fb-16ce-11d7$8645000102 \mathrm{c} 1865 \mathrm{~d}$

Dill,H., Teshner,M.,Wehner,H., 1988,Petrography, Inorganic and Organic Geochemistry of Lower Permian Carboniferous Fan Sequences (Brandschiefer Series) FRG: Constraints to their Palaeogeography and Assessment of their Source Rock Potential: Chemical Geology, 67 (3-4), 307-325. https://doi. org/10.1016/0009-2541(88)90136-2

Dunham. R. J., 1962, Classification of carbonate rocks according to depositional texture: American Association of Petroleum Geologists Bulletin, 1, 108 - 121.

Einsele, G., 2000, Sedimentary Basin: Evolution, Facies and Sediment Budget: Springer Verlag, 292p. https://doi.org/10.1016/ s0037-0738 (01)00061-6

Etesampour, A., Mahboubi, A., MoussaviHarami, R., Arzani, N., Salehi, M. A., 2019, Sandstone petrography and geochemistry of the Nayband Formation (Upper Triassic, Central Iran): Implications for sediment provenance and tectonic setting: Austrian Journal of Earth Sciences, 112 (1), 20-41.

Fathy, D., Wagreich, M., Zaki, R., Mohamed, R.S., Gier, S., 2018, Geochemical fingerprinting of Maastrichtian oil shales from the Central Eastern Desert, Egypt: Implications for provenance, tectonic setting, and source area weathering: Geological Journal, 53(6), 25972612. https://doi.org/10.1002/gj.3094
Fielding, G.R., Frank, T.D., 2015, Onset of the glacioeustatic signal recording late Palaeozoic Gondwanan ice growth: New data from palaeotropical East Fife, Scotland: Palaeogeography, Palaeoclimatology, Palaeoecology, 426, 121-138. https://doi. org/10.1016/j.palaeo.2015.03.002

Fleming, E., Flowerdew, M.J., Smyth, H.R., Scott, R.A., Morton, A.C., Omma, J.E., Frei, D., Whitehouse, M.J., 2016, Provenance of Triassic sandstones on the southwest Barents Shelf and the implication for sediment dispersal patterns in northwest Pangaea: Marine and Petroleum Geology, 78, 516-535. https://doi.org/10.1016/j. marpetgeo.2016.10.005

Flugel, E., 2010, Microfacies of carbonate rocks, analysis interpretation and application: Springer, 976p. https://doi. org/10.1007/978-3-642-03796-2_11

Folk, E., 1980, Petrography of Sedimentary Rocks: Hemphill Publishing Company, 182p.

Fürsich, F.T., Hautmann, M.T., SenowbariDaruan, B., Seyed-Emami, K., 2005, The Upper Triassic Nayband and Darkuh formations of east-central Iran: Stratigraphy, facies patterns and biota of extensional basins on an accreted terrance: Beringeria, 35, 53-133.

Fürsich, F.T., Wilmsen, M., Seyed-Emami, K., Majidifard, M.R., 2009, Lithostratigraphy of the Upper Triassic-Middle Jurassic Shemshak Group of Northern Iran, in Brunet, M.F., Wimsen, M. and Granath, J.W. (ed.), South Caspian to Central Iran Basins: Geological Society of London, Special Publications, 312(1), 129-160. https://doi. org/10.1144/sp312.6

García, D., Ravenne, C., Maréchal, B., Moutte, J., 2004, Geochemical variability induced by entrainment sorting: quantified signals for provenance analysis: Sedimentary Geology, 171(1), 113-128. https://doi.org/10.1016/j. sedgeo.2004.05.013 
Garzanti, E., Resentini, A., 2016, Provenance control on chemical indices of weathering (Taiwan river sands): Sedimentary Geology, 336, 81-95. http:// dx.doi.org/10.1016/j. sedgeo.2015.06.013

Geel, T., 2000, Recognition of stratigraphic sequences in carbonate platform and slope deposits, empirical models based on microfacies analysis of Paleogene deposits in southeastern Spain: Palaeogeograohy, Palaeoclimatology, Palaeoecology, 155(3-4), 211-238. https://doi.org/10.1016/s00310182 (99)00117-0

Getaneh, W., 2002, Geochemistry provenance and depositional tectonic setting of the Adigrat Sandstone northern Ethiopia: Journal of African Earth Sciences, 35(2), 185-198. https://doi.org/10.1016/s08995362 (02)00126-4

Ghasemi, A., Talbot, G.J., 2006, A new tectonic scenario for the Sanandaj-Sirjan Zone (Iran): Journal of Asian Earth Sciences, 26, 683-693. https://doi.org/10.1016/j. jseaes.2005.01.003

Gingras, M.K., MacEachern, J.A., Dashtgard, S. E, 2011, The potential of trace fossils as tidal indicators in bays and estuaries: Sedimentary Geology, 279, 97-106. https:// doi.org/10.1016/j.sedgeo.2011.05.007

Golonka, J., 2004, Plate tectonic evolution of the southern margin of Eurasia in the Mesozoic and Cenozoic: Tectonophysics, 381(1), 235-273. https://doi.org/10.1016/j. tecto.2002.06.004

Grabau, A. W., 1904, On the classification of sedimentary rocks: American Geology, 33, 228-247.

Harms, J. C., Southard, J. B., Walker, R. G., 1982, Structures and Sequence in Clastic Rock: SEPM, Short Course, Chapter 1, 55p.

Hayashi, K.I., Fujisawa, H., Holland, H.D., Ohmoto, H., 1997, Geochemistry of 1.9 Ga sedimentary rocks from northeastern Labrador: Geochimica et Cosmochimica Acta, 61(19), 4115-4137. https://doi. org/10.1016/s0016-7037 (97)00214-7
Higgs, K.E., King, P.R., Raine, J.I., Sykes, R., Browne, G.H., Crouch, E., Baur, J.R., 2012, Sequence stratigraphy and controls on reservoir sandstone distribution in an Eocene marginal marine-coastal plain Fairway, Taranaki Basin, New Zealand: Marine and Petroleum Geology, 30, 175-192. https:// doi.org/10.1016/j.marpetgeo.2011.12.001

Ingersoll, R.V., Suczek, C.A., 1979, Petrology and provenance of Neogene sand from Nicobar and Bengal fans, DSDP sites 211 and 218: Journal of Sedimentary Petrology, 49(4), 1217 1228. https://doi.org/10.1306/212f78f12b24-11d7-8648000102c1865d

Iqbal, S., Wagreich, M., Kuerschner, W.M., Gier, S., Bibi, M., 2019, Hot-house climate during the Triassic/Jurassic transition: The evidence of climate change from the southern hemisphere (Salt Range, Pakistan): Global and Planetary Change, 172, 15-32. https:// doi.org/10.1016/j.gloplacha.2018.09.008

Jones, B., Manning, D.C., 1994, Comparison of Geochemical Indices Used for the Interpretation of Paleo-redox Conditions in Ancient Mudstones: Chemical Geology, 111(1-4), 111-129. https://doi. org/10.1016/0009-2541 (94)90085-x

Khanehbad,M.,Moussavi-Harami,R., Mahboubi, A., Nadjafi, M., Mahmudy Gharaie, M.H., 2012a, Geochemistry of Carboniferous Sandstones (Sardar Formation), East-Central Iran: Implication for Provenance and Tectonic Setting: Acta Geologica SinicaEnglish Edition, 86(5), 1200-1210. https:// doi.org/10.1111/j.1755-6724.2012.00741.x

Khanehbad, M., Moussavi-Harami, R., Mahboubi, A., Nadjafi, M., 2012b, Geochemistry of Carboniferous Shales of the Sardar Formation, East Central Iran: Implication for Provenance, Paleoclimate and Paleo oxygenation Conditions at a Passive Continental Margin: Geochemistry International, 50(9), 777-790. https://doi. org/10.1134/s0016702912090029

Kluyver, H.M., Triw, R., Chance, P.N., Johns, G.W., Meixner, H. M., 1983, Explanatory 
text of the Naibandan Quadrangle map, 1: 250000, Geological Survey of Iran, Reportes, 18, 143p.

Kosters, E.C., 1989, Organic-clastic facies relationships and chronostratigraphy of the Barataria interlobe basin, Mississippi delta plain: Journal of Sedimentary Petrology, 59, 98-113. https://doi.org/10.1306/212fof2b2b24-11d7-8648000102c1865d

Kumar, R., Suresh, N., Satish, J., Sangode, J., Kumaravel, V., 2007, Evolution of the Quaternary alluvial fan system in the Himalayan foreland ba sin implications for tectonic and climate decoupling: Quaternary International, 159, 6-20. https://doi. org/10.1016/j.quaint.2006.08.010

Lee, H.S., Chough, S.K., 2006, Lithostratigraphy and depositional environments of the Pyeongan Super group (CarboniferousPermian) in the Taebaek area mid-east Korea: Journal of Asian Earth Sciences, 26, 339-352. https://doi.org/10.1016/j. jseaes.2005.05.003

Lee, Y.I., 2002, Provenance derived from the geochemistry of late Paleozoic-Early Mesozoic mudrocks of the Pyeongan Supergroup, Korea: Sedimentary Geology, 149(4), 219-235. https://doi.org/10.1016/ s0037-0738 (01)00174-9

Longhitano, S.G., Mellere, D., Steel, R.J., Ainsworth, R.B., 2012, Tidal depositional systems in the rock record: A review and new insights: Sedimentary Geology, 279, 2-22. https://doi.org/10.1016/j. sedgeo.2012.03.024

Miall, A.D., 2000, Principle of Sedimentary Basin Analysis: Springer-Verlag, New York, 668p. https://doi. org/10.1007/978-1-4757-4235-0

Miall, A.D., 2006, The Geology of Fluvial Deposits (3rd edition): SpringerVerlag, Berlin, 582p. https://doi. org/10.1007/978-3-662-03237-4

Mishra, M., Sen, S., 2012, Provenance, tectonic setting and source-area weathering of Mesoproterozoic Kaimur Group, Vindhyan
Supergroup, Central India: Geologica Acta, 10 (3), 283-293. https://doi.org/10.1007/ s11631-010-0021-1

Motiei, H., 1994, Geology of Iran: Stratigraphy of Zagros. Tehran: Geological survey of Iran, 583p. (In Persian).

Moussavi-Harami, S.R., Ghaemi, F., 2006, Korit Geological Map (1:100000), Tehran: Geological Survey and Mineral Exploration of Iran.

Nesbitt, H., Young, G.M., 1982, Early Proterozoic climates and plate motions inferred from major element chemistry of lutites: Nature, 299, 715-717. https://doi. org/10.1038/299715a0

Nesbitt, H.W., Young, G.M., 1984, Prediction of some weathering trends of plutonic and volcanic rocks based on thermodynamic and kinetic considerations: Geochimica et Cosmochimica Acta, 48(7), 1523-1534. https://doi.org/10.1016/0016-7037 (84)90408-3

Nützel, A., Mannani, M., Senowbari-Daryan, B., Yazdi, M., 2010, Gastropods from the Late Triassic Nayband Formation (Iran), their relationships to other Tethyan faunas and remarks on the Triassic gastropod body size problem: Neues Jahrbuch für Geologie und PaläontologieAbhandlungen, 256 (2), 213-228. https:// doi.org/10.1127/0077-7749/2010/0049

Osae, S., Asiedu, D.K., Banoeng-Yakubo, B., Koeberl, C., Dampare, S.B., 2006, Provenance and tectonic setting of Late Proterozoic Buem sandstones of southeastern Ghana: Evidence from geochemistry and detrital modes: Journal of African Earth Sciences, 44(1), 85-96. https://doi.org/10.1016/j. jafrearsci.2005.11.009

Ozkan,A.M.,Ayaz-Bozdag,A., 201 1, Geochemistry and Provenance of Maastrichtian Clastic Rocks in the Dikmendede Formation of Orhaniye in Kazan-Ankara-Turkey Region: Acta Geologica Sinica-English Edition, 85(5), 1067-1083. https://doi. org/10.1111/j.1755-6724.2011.00541.x 
Paikaray, S., Banerjee, S., Mukherji, S., 2008, Geochemistry of shales from the Paleoproterozoic to Neoproterozoic Vindhyan Supergroup: Implications on provenance, tectonics and paleoweathering: Journal of Asian Earth Sciences, 32(1), 34-48. https:// doi.org/10.1016/j.jseaes.2007.10.002

Pettijohn, F.J., 1975, Sedimentary Rocks: Third Edition, Harper and Row, New York, 628p.

Pettijohn, F.J., Potter, P.E., Siever, R., 1987, Sand and Sandstone: (2nd) SpringerVerlag, New York, 553p. https://doi. org/10.1007/978-1-4612-1066-5

Potter, P.E., Maynard, J.B., Depetris, P.J., 2005. Mud and Mudstone: Introduction and overview: Springer-Verlag Berlin Heidelberg, 297p. https://doi.org/10.1007/b13857 1

Quanren, Y., Shanling, G., Zongqi, W., Jiliang, L., Wenjiao, X., Quanling, H., Zhen, Y., Haihong, C., 2002, Geochemical constraints of sediments on the provenance, depositional environment and tectonic setting of the songliao prototype basin: Acta Geologica Sinica-English Edition, 76(4), 455-462. https://doi.org/10.1111/j.1755-6724.2002. tb00099.x

Read,J.F., 1985, Carbonate platform facies models: AmericanAssociation of Petroleum Geologists Bulletin, 69, 1-12. https://doi.org/10.1306/ ad461b79-16f7-11d7-8645000102c1865d

Roser, B. P., Korsch, R. J., 1986, Determination of tectonic setting of sandstone-mudstone suites using $\mathrm{SiO} 2$ content and $\mathrm{K} 2 \mathrm{O} / \mathrm{Na} 2 \mathrm{O}$ ratio: The Journal of Geology, 94, 635-650. https://doi.org/10.1086/62907 1

Roser, B.P., Korsch, R.J., 1988, Provenance signatures of sandstone-mudstone suites determined using discriminant function analysis of major-element data: Chemical Geology, 67(1-2), 119-139. https://doi. org/10.1016/0009-2541 (88)90010-1

Sabbagh Bajestani, M., Mahboubi, A., MoussaviHarami, R., Nadjafi, M., 2018, Petrography and geochemistry of sandstones succession of the Qal'eh Dokhtar Formation
(Middle-Upper Jurassic), east central Iran: Implications for provenance, tectonic setting and palaeoweathering: Journal of African Earth Sciences, 147, 523-535. https://doi. org/10.1016/j.jafrearsci.2018.07.018

Saidi, M., Masoudi, M., Nazemi, M., Faridi, M., Naimi - Ghassabian, N., 2006, GharbE-Shekasteh Abshaleh Geological Map (1:100000), Tehran: Geological Survey and Mineral Exploration of Iran.

Sajjadi, F., Hashemi, H., Borzuee, E., 2015, Palynostratigraphy of the Nayband Formation, Tabas, Central Iran Basin: Paleogeographical and paleoecological implications: Journal of Asian Earth Sciences, 111, 553-567. https://doi.org/10.1016/j. jseaes.2015.05.030

Salehi, M. A., Mazroei Sebdani, Z., Pakzad, H.R., Bahrami, A., Fürsich, F.T., Heubeck, C., 2018, Provenance and palaeogeography of upper most Triassic and Lower Cretaceous terrigenous rocks of central Iran: Reflection of the Cimmerian events: Neues Jahrbuch für Geologie und Paläontologie-Abhandlungen, 288, 49-77. https://doi.org/10.1127/ njgpa/2018/0723

Salehi, M.A., Moussavi-Harami, S.R., Mahboubi, A., Wilmsen, M., Heubeck, C., 2014, Tectonic and palaeogeographic implications of compositional variations within the siliciclastic Ab-Haji Formation (Lower Jurassic, east-central Iran): Neues Jahrbuch für Geologie und PaläontologieAbhandlungen, 271(1), 21-48. https://doi. org/10.1127/0077-7749/2014/0373

Schieber, J., 1992, A combined petrographicalgeochemical provenance study of the Newland Formation, Mid-Proterozoic of Montana: Geological Magazine, 129(2), 223-237. https://doi.org/10.1017/ s0016756800008293

Şengör, A.M.C., Altıner, D., Cin, A., Ustaömer, T., Hsü, K.J., 1988, Origin and assembly of the Tethyside orogenic collage at the expense of Gondwana Land: Geological 
Society of London, Special Publications, 37(1), 119-181 https://doi.org/10.1144/gsl. sp.1988.037.01.09

Seyed-Emami, K., 2003, Triassic in Iran: Facies, 48(1), 91-106. https://doi.org/10.1007/ bf02667532

Shahrabi, M., 1999, Triassic in Iran. Tehran: Geological Survey of Iran, 279p. (In Persian). Sheikholeslami, M.R., 2016, Tectono-stratigraphic evidence for the opening and closure of the Neotethys Ocean in the southern SanandajSirjan zone, Iran, in Sorkhabi, R., ed., Tectonic evolution, collision, and seismicity of southwest Asia, in honor Manuel Berberian's forty-five years of research contributions: Geological Society of America, Boulder, Colorado, SPE525-09, 319-342.

Shi, G., Wang, H., Huang, C., Yang, S., Song, G., 2016, Provenance and tectonic setting of middle-upper Devonian sandstones in the Qinling Orogen (Shanyang area): New insights from geochemistry, heavy minerals and tourmaline chemistry: Tectonophysics, 688, 11-25. https://doi.org/10.1016/j. tecto.2016.09.023

Stampfli, G.M., Borel, G.D., 2002, A plate tectonic model for the Paleozoic and Mesozoic constrained by dynamic plate boundaries and restored synthetic oceanic isochrones: Earth and Planetary Science Letters, 196(1), 17-33. https://doi.org/10.1016/s0012-821x (01)00588-x

Stöcklin J., 1974, Possible Ancient Continental Margins in Iran, in Burk C.A. and Drake C.L. (ed.), the Geology of Continental Margins. Springer, Berlin, Heidelberg, 873 - $887 . \quad$ https://doi. org/10.1007/978-3-662-01141-6_64

Strand, K., 2005, Sequence stratigraphy of the silisiclastic east Puolanka Group the Palaeoproterozoic Kainuu Belt, Finland: Sedimentary Geology, 176, 149-166. https://doi.org/10.1016/j. sedgeo.2004.12.014

Suttner, L.J., Dutta, P.K., 1986, Alluvial sandstone composition and paleoclimate, I. Framework mineralogy: Journal of Sedimentary Petrology, 56(3), 329-345. https://doi. org/10.1306/212f8909-2b24-11d7$8648000102 \mathrm{c} 1865 \mathrm{~d}$

Taylor, S.R., McLennan, S.M., 1985, The continental crust: its composition and evolution: Blackwell Scientific Publications, Oxford, 312p.

Therrien, F., 2006, Depositional environments and fluvial system changes in the dinosaurbearing Sanpetru Formation (Late Cretaceous, Romania): postorogenic sedimentation in an active extensional basin: Sedimentary Geology, 192, 183-205. https:// doi.org/10.1016/j.sedgeo.2006.04.002

Tijani, M.N., Nton, M.E., Kitagawa, R., 2010, Textural and geochemical characteristics of the Ajali Sandstone, Anambra Basin, SE Nigeria: implication for its provenance: Comptes Rendus Geoscience, 342(2), 136-150. https://doi.org/10.1016/j. crte.2009.09.009

Tovaglieri, F., George, A.D., 2014, Stratigraphic architecture of an Early Middle Jurassic tidally influenced deltaic system (Plover Formation), Browse Basin, Australian North West Shelf: Marine and Petroleum Geology, 49, 59-83. https://doi.org/10.1016/j. marpetgeo.2013.09.011

Tucker, M.E., 2001, Sedimentary Petrology: Third Edition, Blackwell, Oxford, 260p.

Tucker, M.E., 2009, Sedimentary petrology: an introduction to the origin of sedimentary rocks: John Wiley and Sons, 272p.

Von Eynatten, H., Barceló-Vidal, C., PawlowskyGlahn, V., 2003, Composition and discrimination of sandstones: a statistical evaluation of different analytical methods: Journal of Sedimentary Research, 73(1), 4757. https://doi.org/10.1306/070102730047 Walker, R.G., Plint, A.G., 1992, Wave and storm-dominated shallow marine systems, in Walker, R.G., James, N.P. (Eds.), Facies Models: Response to sea level change: 
Geological Association of Canada, GeoText 1, Newfoundland, 219-238.

Weltje, G.J., 2002, Quantitative analysis of detrital modes: statistically rigorous confidence regions in ternary diagrams and their use in sedimentary petrology: Earth-Science Reviews, 57(3), 211-253. https://doi.org/10.1016/ s0012-8252 (01)00076-9

Weltje, G.J., Von Eynatten, H., 2004, Quantitative provenance analysis of sediments: review and outlook: Sedimentary Geology, 171(1), 1-11. https://doi.org/10.1016/j. sedgeo.2004.05.007

Wilmsen, M., Fürsich, F.T., Seyed-Emami, K., Majidifard, M.R., 2009a, An overview of the stratigraphy and facies development of the Jurassic System on the Tabas Block, eastcentral Iran, in Brunet, M.F., Wimsen, M., Granath, J.W. (ed.), South Caspian to Central Iran Basins: Geological Society of London, Special Publications, 312(1), 323-343. https:// doi.org/10.1144/sp312.15

Wilmsen, M., Fürsich, F.T., Seyed-Emami, K., Majidifard, M.R., Taheri, J., 2009b, The Cimmerian Orogeny in northern Iran: Tectono-stratigraphic evidence from the foreland: Terra Nova, 21(3), 211-218. https:// doi.org/10.1111/j.1365-3121.2009.00876.x

Wilmsen, M., Fürsich, F., Seyed-Emami, K., Majidifard, M., Zamani-Pedram, M., 2010, Facies analysis of a largescale Jurassic shelflagoon: the Kamar-e-Mehdi Formation of east-central Iran; Facies, 56, 59-87. https:// doi.org/10.1007/s10347-009-0190-8

Zaid, S.M., 2015, Geochemistry of sandstones from the Pliocene Gabir Formation, north Marsa Alam, Red Sea, Egypt: implication for provenance, weathering and tectonic setting: Journal of African Earth Sciences, 102, 1-17. https://doi.org/10.1016/j. jafrearsci.2014.10.016

Zamaniyan. E., Khanehbad, M., Moussavi-Harami, R., Mahboubi, A., 2019, Geochemistry of shales of the Qadir Member (Nayband Formation, Upper Triassic), East Central Iran (Tabas Block): implications for provenance and palaeogeography: Geological Quarterly, 63 (3), 603-618. https://doi.org/10.7306/ gq. 1491

Zamaniyan. E., Khanehbad, M., Moussavi-Harami, R., Mahboubi, A., 2018, Lithofacies and sedimentary environment of Qadir Member of the Nayband Formation on Parvadeh Coal Mines region, east central of Iran: Scientific QuarterlyJournal, Geosciences, 28 (109), 295304. (In Persian).

Zanchi, A., Zanchetta, S., Garzanti, E., Balini, M., Berra, F., Mattei, M., Muttoni, G., 2009, The Cimmerian evolution of the Nakhlak-Anarak area, Central Iran, and its bearing for the reconstruction of the history of the Eurasian margin: Geological Society, London, Special Publications, 312(1), 261-286. https://doi. org/10.1144/sp312.13

Zhang, K., Li, Z., Yi, C., Li, X., Chen, X., 2014, Compositions of Zhiluo Formation Sandstone of Northeastern Ordos Basin and its Use as a Provenance Indicator: Acta Geologica SinicaEnglish Edition, 88(2), 1426-1427. https:// doi.org/10.1111/1755-6724.12381_42 